\title{
Sources of land-derived runoff to a coral reef-fringed embayment identified using geochemical tracers in nearshore sediment traps
}

\author{
Renee K. Takesue ${ }^{\mathrm{a}, *}$, Michael H. Bothner ${ }^{\mathrm{b}}$, Richard L. Reynolds ${ }^{\mathrm{c}}$ \\ ${ }^{a}$ US Geological Survey, Coastal and Marine Geology, 400 Natural Bridges Drive, Santa Cruz, CA 95060, USA \\ ${ }^{\mathrm{b}}$ US Geological Survey, Woods Hole Coastal and Marine Science Center, 384 Woods Hole Road, Woods Hole, MA 02543, USA \\ ${ }^{\text {c } U S ~ G e o l o g i c a l ~ S u r v e y, ~ D e n v e r ~ F e d e r a l ~ C e n t e r, ~ M S ~ 980, ~ B o x ~ 25046, ~ D e n v e r, ~ C O ~ 80225, ~ U S A ~}$
}

\section{A R T I C L E I N F O}

\section{Article history:}

Received 26 January 2009

Accepted 18 September 2009

Available online 24 September 2009

\section{Keywords:}

sediment traps

provenance

trace elements

radioisotopes

magnetic properties

coral reefs

\begin{abstract}
A B S T R A C T
Geochemical tracers, including $\mathrm{Ba}, \mathrm{Co}, \mathrm{Th},{ }^{7} \mathrm{Be},{ }^{137} \mathrm{Cs}$ and ${ }^{210} \mathrm{~Pb}$, and magnetic properties were used to characterize terrestrial runoff collected in nearshore time-series sediment traps in Hanalei Bay, Kauai, during flood and dry conditions in summer 2006, and to fingerprint possible runoff sources in the lower watershed. In combination, the tracers indicate that runoff during a flood in August could have come from cultivated taro fields bordering the lower reach of the river. Land-based runoff associated with summer floods may have a greater impact on coral reef communities in Hanalei Bay than in winter because sediment persists for several months. During dry periods, sediment carried by the Hanalei River appears to have been mobilized primarily by undercutting of low ${ }^{7} \mathrm{Be}$, low ${ }^{137} \mathrm{Cs}$ riverbanks composed of soil weathered from tholeiitic basalt with low Ba and Co concentrations. Following a moderate rainfall event in September, high ${ }^{7}$ Be sediment carried by the Hanalei River was probably mobilized by overland flow in the upper watershed. Ba-desorption in low-salinity coastal water limited its use to a qualitative runoff tracer in nearshore sediment. ${ }^{210} \mathrm{~Pb}$ had limited usefulness as a terrestrial tracer in the nearshore due to a large dissolved oceanic source and scavenging onto resuspended bottom sediment. ${ }^{210} \mathrm{~Pb}-$ scavenging does, however, illustrate the role resuspension could play in the accumulation of particlereactive contaminants in nearshore sediment. Co and ${ }^{137} \mathrm{Cs}$ were not affected by desorption or geochemical scavenging and showed the greatest potential as quantitative sediment provenance indicators in material collected in nearshore sediment traps.
\end{abstract}

Published by Elsevier Ltd.

\section{Introduction}

Runoff of nutrients, sediment, and contaminants from land is the largest source of pollution to marine waters and has harmful impacts on nearshore ecosystems (Fabricius, 2005; UNEP/GPA, 2006). Shallow water communities such as coral reefs are particularly vulnerable to the effects of terrestrial runoff because they are close to land and are sensitive to changes in water quality (Jackson et al., 2001; Bellwood et al., 2004; Fabricius, 2005). In coastal regions with coral reefs, population growth, coastal development, and reef exploitation are contributing factors in the observed decline in coral reef ecosystems worldwide (Gardner et al., 2003; McCulloch et al., 2003; Bellwood et al., 2004; Wilkinson, 2004; Pandolfi et al., 2005). The Hawaiian Islands provide many examples of coral decline in regions with large population and impaired

\footnotetext{
* Corresponding author.

E-mail addresses: rtakesue@usgs.gov (R.K. Takesue), mbothner@usgs.gov (M.H Bothner), rreynolds@usgs.gov (R.L. Reynolds).
}

watersheds (Jokiel et al., 2004). To reduce threats to its coral reefs, the state of Hawaii is working to reduce land-derived sediment and pollutant runoff.

This study explores whether geochemical and magnetic properties in nearshore trapped sediment can be used to identify source regions of eroded terrestrial sediment in the Hanalei watershed, and to trace its dispersal in coral reef-fringed Hanalei Bay, Kauai. The watershed is characterized by heavy precipitation, steep hill slopes, areas denuded of vegetation, cultivated farmland and a flood-prone river. An understanding of sediment erosion patterns will allow mitigation strategies to target regions or land-use practices that contribute to nearshore sedimentation.

We used select trace elements, atmospheric-fallout radioisotopes and magnetic properties to characterize, or fingerprint, nearshore and terrestrial sediment. Sediment trace element chemistry reflects the composition of the parent rock, chemical weathering, sorting during transport, and post-depositional diagenesis (McLennan et al., 1993). Elements such as aluminum $(\mathrm{Al})$, cobalt $(\mathrm{Co})$ and thorium (Th) that are relatively immobile in rocks and sediment are the most useful provenance indicators 
because sediment concentrations are likely to be quantitatively related to the parent rock compositions (McLennan et al., 1990; Condie, 1993; Rollinson, 1993; Fralick and Kronberg, 1997). Barium (Ba) is easily mobilized from parent rocks but it is strongly retained by secondary clays and so is relatively fixed during continental weathering (Nesbit et al., 1980). Normalization of elemental concentrations by $\mathrm{Al}$ accounts for grain size effects and shows deviations from natural abundances which may be related to anthropogenic inputs (Windom et al., 1989). Magnetic iron oxide minerals originate primarily in igneous rocks and some soil. Magnetic properties may reflect sources and landscape settings of upland sediment because mineral types and magnetic domain sizes (magnetic grain sizes) vary among volcanic sediment representing differing magmatic composition and cooling as well as weathering history (Reynolds et al., 1990; Rosenbaum et al., 1991, 1994). The radioisotopes ${ }^{7} \mathrm{Be}$ (53-day half-life) and ${ }^{137} \mathrm{Cs}$ (30-year half-life) are present in the system largely from atmospheric deposition on terrestrial particles in the watershed. The presence of these isotopes in marine sediment reflects inputs of terrigenous material. Due to its short half-life, ${ }^{7} \mathrm{Be}$ occurs in soil or sediment that has been in contact with the atmosphere within about the last 9 months, or five half-lives. The unique input function of ${ }^{137} \mathrm{Cs}$ from nuclear weapons testing, which resulted in ${ }^{137} \mathrm{Cs}$ fallout that peaked in 1963 and has been negligible since (Garcia-Agudo, 1998), identifies sediment or mixtures of sediment that were exposed to the atmosphere $40-60$ years ago. ${ }^{210} \mathrm{~Pb}$ (22-year halflife) has both atmospheric and marine sources (Rama et al., 1961) and contributes supporting information about sediment accumulation. Throughout this discussion, ${ }^{210} \mathrm{~Pb}$ refers to excess ${ }^{210} \mathrm{~Pb}$, that is the amount in sediments in excess of the activity supported by parent isotope ${ }^{222} \mathrm{Rn}$ in the ${ }^{238} \mathrm{U}$ decay chain (Ivanovich et al., 1992). ${ }^{7} \mathrm{Be}$ and ${ }^{210} \mathrm{~Pb}$ are delivered to the land surface mainly by precipitation and become strongly bound to fine particles. Because precipitation patterns vary in space and time, atmospheric fluxes of ${ }^{7} \mathrm{Be}$ and ${ }^{210} \mathrm{~Pb}$ may be highly variable within a study area. The ${ }^{7} \mathrm{Be} /{ }^{210} \mathrm{~Pb}$ activity ratio, however, may be less variable than the individual isotope fluxes (Baskaran and Santschi, 1993; Koch et al., 1996; McNeary and Baskaran, 2003), and furthermore is not affected by differences in the proportion of fine sediment among sites (Matisoff et al., 2005).

\section{Study site}

Kauai is the only main Hawaiian island where coral reefs have expanded significantly in the last 5 years (Jokiel et al., 2004), and it is also among the least populous of the major islands. In northfacing Hanalei Bay (Fig. 1a), coral cover has increased during the past decade, despite the fact that exposure to high wave energy in winter keeps total coral cover at only 15\% (Brown and Friedlander, 2007). Sediment and contaminant loading are concerns for the health of the coral reef community in Hanalei Bay because the Hanalei River often exceeds Federal water quality standards for turbidity and enterococcus bacteria set by US Environmental Protection Agency Section 303(d) of the Clean Water Act (EPA, 2008). Furthermore, organochlorine pesticides, polycyclic aromatic hydrocarbons, and heavy metals have been detected in biota and sediment of the lower Hanalei River, but mostly below levels of concern (Orazio et al., 2007).

\subsection{Hanalei watershed and river characteristics}

The $54.4 \mathrm{~km}^{2}$ Hanalei watershed occupies a steep-sided valley eroded down into shield-stage tholeiitic lavas of the Waimea Canyon Basalt deposited 2-4 Ma (MacDonald et al., 1960; Clague and Dalrymple, 1988). The east wall of Hanalei Valley was formed by postshield rejuvenated-stage Koloa lava flows (0.5-1.5 Ma) and consists of alkali basalt (Feigenson, 1984; Clague and Dalrymple, 1988; Reiners and Nelson, 1998). In the upper watershed, mass wasting of weathered basalt and soil overland flow are associated with rainfall events (Calhoun and Fletcher, 1999) and are a major source of sediment to the Hanalei River. Denudation of vegetation and soil disturbance by wild pigs contribute to soil erosion (Smith and Hanson, 2007).

Mt. Waialeale, $1569 \mathrm{~m}$ above sea level, forms the headwaters of the Hanalei River. The river flows $25.2 \mathrm{~km}$ northward to the sea and is confined to the valley (upland) until about $11 \mathrm{~km}$ from the coast, where a broad floodplain begins $6 \mathrm{~m}$ above sea level (Calhoun and Fletcher, 1996). Abandoned floodplains form terraces 3-8 $\mathrm{m}$ above the present river bed (Roesner, 2007). The lower $5.6 \mathrm{~km}$ of the Hanalei River is estuarine and passes through the Hanalei National Wildlife Refuge, where taro crops are cultivated. During 19932006, the median flow rate at a US Geological Survey (USGS) river gage $9.2 \mathrm{~km}$ upstream of the mouth of Hanalei River was $3.8 \mathrm{~m}^{3} \mathrm{~s}^{-1}$, and the highest daily flow rate was $201.0 \mathrm{~m}^{3} \mathrm{~s}^{-1}$ on November 3 , 1995 (Tribble and Hill, 2007).

\subsection{Hanalei climate and oceanography}

The majority of rainfall on Kauai is orographic and occurs in the upper watershed as humid air masses associated with northeast trade winds ascend the slopes of Mt. Waialeale and cool as they rise. The trade winds prevail for the majority of the year, which accounts for extremely high annual rainfall totals at the peak of Mt. Waialeale, $1010 \mathrm{~cm}_{\text {year }}{ }^{-1}$. In the lower watershed, precipitation varies seasonally. Winter rainfall maxima are caused by storms moving from the south or southwest. Annual rainfall is around $290 \mathrm{~cm}$ year $^{-1}$ at 90 m elevation and $180 \mathrm{~cm}$ year $^{-1}$ at sea level (MacDonald et al., 1960).

The water column of Hanalei Bay experiences two seasonal oceanographic regimes. Summers are relatively quiescent; significant wave heights are about $0.5 \mathrm{~m}$ at $4 \mathrm{~s}$ intervals (Storlazzi et al., 2006). Surface water enters Hanalei Bay from the northeast, flows clockwise around the bay and exits to the northwest while currents near the bottom flow in the opposite direction (Storlazzi et al., 2006). Land-derived sediment and pollutant inputs into Hanalei Bay may persist longer in summer than at other times of the year due to a lower flushing rate (Draut et al., 2006). In winter, the North Pacific swell brings large waves from the northwest with wave heights from 2 to $5 \mathrm{~m}$ at 12-20 s periods (Moberly and Chamberlain, 1964). Such energetic oceanographic conditions rapidly transport terrestrial runoff out of Hanalei Bay. The bottom sediment of Hanalei Bay is predominantly carbonate sand except in the bathymetric depression offshore of the river mouth called the Black Hole, which collects both carbonate and terrigenous mud and river debris (Draut et al., 2009).

A summer flood occurred on August 6-7, 2006 (Fig. 2). River discharge increased from an average of $3 \pm 1 \mathrm{~m}^{3} \mathrm{~s}^{-1}(1 \sigma)$ during June and July to $46 \mathrm{~m}^{3} \mathrm{~s}^{-1}$ during the flood, accompanied by an 8 -fold increase in suspended sediment concentration. Salinity measured continuously at 3-m depth at the sediment trap site offshore of Hanalei River decreased from 34.9 to 33.6 during peak outflow (Storlazzi et al., 2008). The 3-m sensor probably did not capture the full extent of the flood-related salinity decrease, however, because water column profiles of salinity show that the flood plume occurred in the uppermost 1-2 $\mathrm{m}$ of the water column (Storlazzi et al., 2008). The mud content and ${ }^{7} \mathrm{Be}$ and ${ }^{137} \mathrm{Cs}$ activities in the bottom sediment of Hanalei Bay suggest that sediment deposition from flood plumes is limited to the eastern side of the bay (Cochran et al., 2007; Draut et al., 2009). 


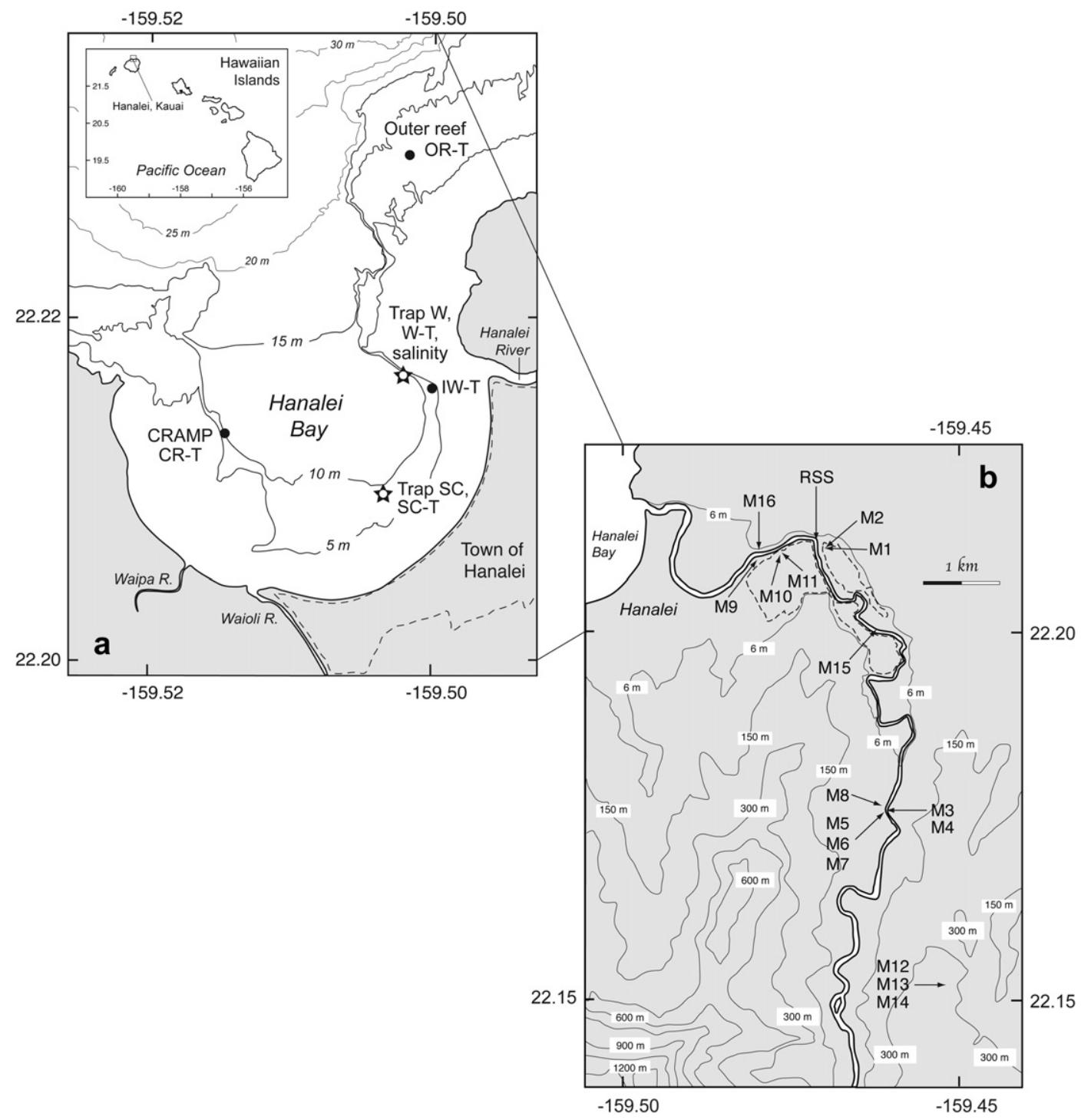

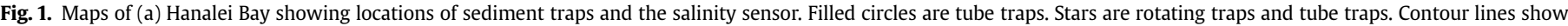

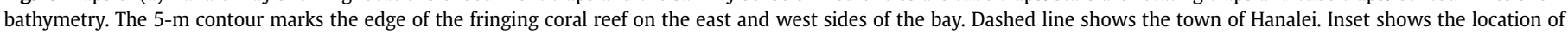

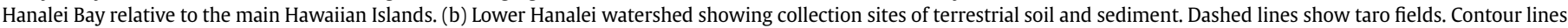
show elevation. The floodplain is below the 6-m elevation contour (Calhoun and Fletcher, 1996). The interval for all other contour lines is $150 \mathrm{~m}$.

\section{Methods}

\subsection{Sediment collection}

\subsubsection{Nearshore sediment traps}

Sediment traps were used to determine the relative quantity and composition of material settling through the water column in different regions of Hanalei Bay. A time-series trap designed for use in the deep ocean (McLane Research Laboratories, 1994) was modified for near-bottom shallow water deployment (Bothner et al., 2007) in order to collect material during and between sediment transport events caused by river floods or wave-induced sediment resuspension. It is important to note that in this setting, traps do not quantify net sediment accumulation or net chemical fluxes to the sea floor (Bothner et al., 2007). This limitation is related to the frequency of sediment resuspension and to the unknown collection efficiency of traps in wave-induced oscillatory currents. Trap-collection efficiencies are difficult to quantify even in unidirectional currents in nature (Baker et al., 1988) and in flume studies (White, 1990).
Tube traps and/or rotating time-series traps, were deployed at five sites in Hanalei Bay from June 6 to September 9, 2006 (Fig. 1a, Table 1). The tube traps were $30 \mathrm{~cm}$-long, $6.7 \mathrm{~cm}$-diameter clear polycarbonate tubes topped with a 5-cm thick "honeycombed" baffle to reduce turbulence and to prevent entry by large aquatic organisms. The openings of tube traps were $0.4 \mathrm{~m}$ above the seafloor. Tube trap material was subsampled by depth intervals, but in most cases composite values are used for each trap. The suffix ' $T$ ' denotes tube traps. Time-series traps have a $20 \mathrm{~cm}$-diameter $75 \mathrm{~cm}$-long cylinder-funnel collection apparatus that directs material into individual $500 \mathrm{ml}$ polyethylene collection bottles on a 21-bottle rotating carousel. The tops of the time-series traps were $1.4 \mathrm{~m}$ above the sea floor and were also fitted with a $5 \mathrm{~cm}$ thick baffle. The carousel rotates at a programmable interval, here 4.5 days, so that the start and end date of sediment accumulation in each bottle is known precisely. Material in each rotating trap bottle was analyzed in bulk and represents a 4.5 day average. The exception was material in bottle 14 of Trap W (14W), which was subsampled at approximately $0-1,1-5,5-10,10-15$, and $15-20 \mathrm{~cm}$ intervals from top to bottom with plastic spoons. The dates of 


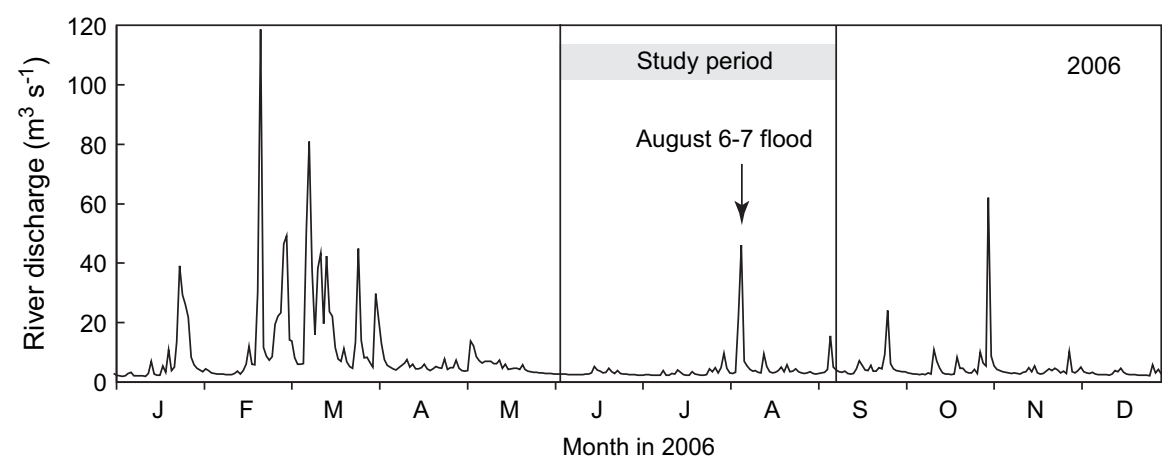

Fig. 2. Hanalei River discharge during 2006 measured at the USGS river gage (16103000) 9 km upstream.

deposition of bottle $14 \mathrm{~W}$ subsamples were estimated by linear interpolation. Preservatives were not added to sediment traps, so sediment microbial reduction-oxidation (redox) reactions could have altered redox-sensitive metal concentrations, such as manganese and iron, in sediment and overlying water. Time-series traps were deployed only at the sites $440 \mathrm{~m}$ west of the river mouth (Trap W) and $915 \mathrm{~m}$ southwest of the river mouth (Trap SC) (Fig. 1a). All sediment traps were deployed at 10 -m water depth, except trap IW-T, which was at 5-m depth.

\subsubsection{Terrestrial soil, riverbank, and suspended sediment}

Terrestrial soil and river sediment were collected along the lowermost $\sim 10 \mathrm{~km}$ of the Hanalei River and valley on September 1213, 2006 (Fig. 1b, Table 1). The upper watershed was not accessible by road or river and was therefore not sampled. Sample locations targeted sedimentary environments that are potential sources of sediment to the Hanalei River: riverbanks, floodplains, cultivated taro fields and hill slopes of the Hanalei Valley. Terrestrial soil or sediment samples are prefixed by the letter ' $M$ '. One sample of river suspended sediment was collected a few meters upstream of the highway bridge over the Hanalei River on September 6, 2006, following a modest storm when daily river discharge was $15.6 \mathrm{~m}^{3} \mathrm{~s}^{-1}$. Approximately 751 of near-surface river water and particles were collected in the river where the current was strong and turbulent. Whole-water samples were left undisturbed, covered and in the shade, to allow particles to settle. After 5 days, the overlying water was siphoned off. The remaining particles were operationally defined as river suspended sediment (RSS). Since this storm did not extensively over-top the river banks, the properties and provenance of the RSS may be somewhat different than RSS associated with the major flood of August 6-7.

\subsection{Collection rate, grain size, organic carbon and carbonate analyses}

Mass accumulation rates in sediment trap bottles were calculated from the dry weight of material and the cross sectional area of the trap mouth. Grain size, organic carbon and carbonate were measured in aliquots of select time-series and upland samples. Grain size distributions of nearshore and terrestrial sediment were measured in different ways. Nearshore sediment was wet-sieved through a $63 \mu \mathrm{m}$-mesh sieve with distilled water to separate sand

Table 1

Hanalei Bay and watershed sample locations and descriptions.

\begin{tabular}{|c|c|c|c|}
\hline Site and abbreviation & Latitude & Longitude & Description \\
\hline \multicolumn{4}{|l|}{ Nearshore sediment traps } \\
\hline Inshore river (IW-T) & 22.214 & -159.500 & Tube trap $293 \mathrm{~m}$ from river mouth \\
\hline Offshore river (Trap W) & 22.214 & -159.501 & Time-series trap $440 \mathrm{~m}$ from river mouth \\
\hline Offshore river $(\mathrm{W}-\mathrm{T})$ & 22.214 & -159.501 & Tube trap $440 \mathrm{~m}$ from river mouth \\
\hline South-Central (Trap SC) & 22.211 & -159.512 & Time-series trap $915 \mathrm{~m}$ from river mouth \\
\hline South-Central (SC-T) & 22.214 & -159.501 & Tube trap $915 \mathrm{~m}$ from river mouth \\
\hline CRAMP (CR-T) & 22.209 & -159.503 & Tube trap $1,527 \mathrm{~m}$ from river mouth \\
\hline Outer reef $(\mathrm{OR}-\mathrm{T})$ & 22.226 & -159.501 & Tube trap $1,256 \mathrm{~m}$ from river mouth \\
\hline \multicolumn{4}{|l|}{ Upland soil and sediment } \\
\hline Cultivated field (M1A-B) & 22.211 & -159.474 & A: At weir gate, B: $3 \mathrm{~m}$ upstream of weir gate \\
\hline Cultivated field (M2) & 22.210 & -159.474 & $0-3 \mathrm{~cm}$ \\
\hline Streambank, upland (M3) & 22.184 & -159.469 & East bank, USGS stream gage $16103000,0-0.5 \mathrm{~cm}$ \\
\hline Streambank, upland (M4) & 22.179 & -159.466 & East bank, $0-1 \mathrm{~cm}$ \\
\hline Streambank, upland (M5) & 22.180 & -159.455 & West bank, $185 \mathrm{~cm}$ below bank \\
\hline Streambank, upland (M6) & 22.180 & -159.455 & West bank, $120 \mathrm{~cm}$ below bank \\
\hline Streambank, upland (M7) & 22.180 & -159.455 & West bank, $0-5 \mathrm{~cm}$ (top of bank) \\
\hline Forest soil (M8A-C) & 22.180 & -159.466 & West bank, A: $0-2 \mathrm{~cm}, \mathrm{~B}: 2-4 \mathrm{~cm}, \mathrm{C}: 4-6 \mathrm{~cm}$ \\
\hline Grassy field (M9A-C) & 22.209 & -159.483 & $3 \mathrm{~m}$ from river; A: $0-2 \mathrm{~cm}, \mathrm{~B}: 2-4 \mathrm{~cm}, \mathrm{C}: 4-6 \mathrm{~cm}$ \\
\hline Cultivated field (M10) & 22.208 & -159.480 & $0-2 \mathrm{~cm}$ \\
\hline Cultivated field (M11) & 22.208 & -159.480 & $0-2 \mathrm{~cm}$ \\
\hline Hillside roadcut (M12A-D) & 22.156 & -159.459 & $\begin{array}{l}\text { A: } 30 \mathrm{~cm} \text { above road, B: } 32-62 \mathrm{~cm} \text { below road, } \mathrm{C}: 2-32 \mathrm{~cm} \\
\text { below road, D: } 0-2 \mathrm{~cm} \text { below road }\end{array}$ \\
\hline Hillside soil (M13) & 22.164 & -159.459 & $0-1 \mathrm{~cm}$ \\
\hline Hillside soil (M14) & 22.150 & -159.459 & $0-2 \mathrm{~cm}$ \\
\hline Streambank, floodplain (M15) & 22.200 & -159.468 & $320 \mathrm{~cm}$ below bank \\
\hline Streambank, floodplain (M16) & 22.209 & -159.483 & $80 \mathrm{~cm}$ below bank \\
\hline River suspended sediment (RSS) & & & Upstream of highway bridge \\
\hline
\end{tabular}


and fine sediment. If gravel was visible, the sample was sieved through a $2 \mathrm{~mm}$ diameter-mesh sieve to separate it from sand. The sand and gravel fractions were dried and weighed individually. Fractional weights of silt and clay were measured on 1-2 ml of the $<63 \mu \mathrm{m}$ wet suspension in a coulter counter. Sediment grain size fractions are reported as percent of total weight (wt\%). Terrestrial sediment particle size was determined as volume percentage using a laser-light scattering method capable of measuring particles between 0.05 and $3480 \mu \mathrm{m}$. Prior to analysis, organic matter was removed using $30 \%$ hydrogen peroxide, and sediment was disaggregated in a Na-hexametaphosphate solution.

The total organic carbon (TOC) content of dried and ground nearshore and terrestrial sediment and soil was measured using a Shimadzu CHNS/O elemental analyzer and is reported as percent of total weight (wt\%). The accuracy of TOC analyses were determined by analyses of an estuarine sediment reference material (MESS-2) from the National Research Council of Canada. The average measured TOC value of MESS-2, $1.49 \pm 0.17 \%(n=4)$ was within the range of literature values. Carbonate content $\left(\mathrm{CaCO}_{3}\right)$ was measured in a UIC Coulometrics coulometer with an acidification unit and reported as percent of total weight (wt\%). The accuracy of $\mathrm{CaCO}_{3}$ measurements was determined by analysis of reagent-grade calcite. Recoveries were $>98 \%$ with a relative standard deviation of $<1 \%$. Uncertainties reported for average TOC and $\mathrm{CaCO}_{3}$ values refer to \pm 1 standard deviation.

\subsection{Elemental compositions}

Contents of major ( $\mathrm{Na}, \mathrm{Mg}, \mathrm{Al}, \mathrm{K}, \mathrm{Ca}, \mathrm{Ti}, \mathrm{Mn}, \mathrm{Fe}$ ) and trace ( $\mathrm{V}, \mathrm{Cr}, \mathrm{Co}$, $\mathrm{Ni}, \mathrm{Cu}, \mathrm{Zn}, \mathrm{Sr}, \mathrm{Mo}, \mathrm{Cd}, \mathrm{Ba}, \mathrm{Pb}, \mathrm{Th}, \mathrm{U})$ elements in rocks were measured on total digests of the sediment fine fraction $(<63 \mu \mathrm{m})$. Between 2 and $5 \mathrm{~g}$ of wet sediment were dried overnight at $105^{\circ} \mathrm{C}$, cooled in a desiccator and disaggregated with an agate mortar and pestle. The fine fraction was separated from about $1 \mathrm{~g}$ of dry sediment in stainless steel sieves. Sediment was digested according to Method 3052 of the U.S. Environmental Protection Agency (microwave assisted acid digestion of siliceous and organically based matrices). Sediment digests were evaporated to dryness on a hot plate to remove acids, then residues were reconstituted in $2 \%$ Optima $^{\mathrm{TM}}$ grade nitric acid containing a germanium internal standard. Sample solutions were analyzed on a high-resolution Element (Thermo Finnigan) inductively-coupled plasma mass spectrometer (ICP-MS) at the University of California at Santa Cruz. Element-count intensities were normalized by the internal standard to correct for changes in instrument sensitivity and matrix effects. Certified reference materials from the National Institute of Standards and Technology (1646a, 2702) and Canadian Certified Reference Materials Project (STDS-2, STDS-3) and procedural blanks were processed in the same manner as samples and analyzed every 20 samples during each ICP-MS run. Analytical uncertainties, estimated from the precision of reference material determinations, are about $5 \%$ for each element and $7 \%$ for element ratios. Uncertainties reported for average values refer to \pm 1 standard deviation.

When normalized to $\mathrm{Al}$, most minor and trace elements showed no systematic variation in the sediment trap time-series $(\mathrm{Li}, \mathrm{K}, \mathrm{Ti}, \mathrm{V}$, $\mathrm{Cr}, \mathrm{Cd}, \mathrm{U})$, were more closely related to marine carbonate $(\mathrm{Mg}, \mathrm{Ca}$, $\mathrm{Sr}$ ) or seawater $(\mathrm{Na})$, or may have been altered by redox processes ( $\mathrm{Mn}, \mathrm{Fe}, \mathrm{Mo}$ ) and will not be discussed further.

\subsection{Radioisotope analyses}

Activities of ${ }^{7} \mathrm{Be},{ }^{137} \mathrm{Cs}$, and ${ }^{210} \mathrm{~Pb}$ in bulk sediment were measured on planar germanium gamma detectors (Canberra Industries, Inc., model GS2020S) at the USGS in Woods Hole, Massachusetts. Homogenized wet sediment was freeze-dried, and then disaggregated in an agate mortar and pestle. Water loss during freeze-drying and measured salinity were used to calculate salt content in dried marine samples. A maximum of $58 \mathrm{~g}$ of dry sediment was placed in screw top plastic jars for gamma counting. The samples were generally counted for $48-96 \mathrm{~h}$ or until the ${ }^{210} \mathrm{~Pb}$ counting error was less than $3 \%$. Radioisotope activities were quantified using their characteristic gamma peaks at $477.6 \mathrm{keV}\left({ }^{7} \mathrm{Be}\right), 661.6 \mathrm{keV}\left({ }^{137} \mathrm{Cs}\right)$, and $46.5 \mathrm{keV}\left({ }^{210} \mathrm{~Pb}\right)$. Excess ${ }^{210} \mathrm{~Pb}$ activity was calculated by subtracting ${ }^{214} \mathrm{~Pb}$ counts at $352 \mathrm{keV}$ from the activity of total ${ }^{210} \mathrm{~Pb}$ at $46.5 \mathrm{keV}$ (Joshi, 1987). The activities of ${ }^{7} \mathrm{Be},{ }^{137} \mathrm{Cs}$, and excess ${ }^{210} \mathrm{~Pb}$ were corrected for self-absorption using the method of Cutshall et al. (1983) and decay-corrected to the date of collection. Detector efficiency over the energy range 46.5-352 keV was determined using EPA standard pitchblende ore. The efficiency at $661.6 \mathrm{keV}$ was determined using a liquid ${ }^{137} \mathrm{Cs}$ standard solution from Isotope Products Laboratory, and at $477.6 \mathrm{keV}$ by interpolation between 352 and $661.6 \mathrm{keV}$. Standards were in the same geometry and height range as the samples. Measured activities of standard reference materials were accurate within $5 \%$ of certified values. Samples with counting errors $>40 \%$ were considered to be below limits of determination. Radioactivities are reported in units of disintegrations per minute (dpm) per gram of sediment. One dpm is equivalent to $1 / 60$ becquerels (Bq, equivalent to disintegrations per second).

\subsection{Magnetic properties}

Magnetic properties of Hanalei Bay trapped sediment and terrestrial soil or sediment were measured on dried sediment packed into $3.2 \mathrm{~cm}^{3}$ plastic cubes. Magnetic susceptibility (MS) is a measure of the concentration of magnetic grains. Ferrimagnetic minerals, especially magnetite, dominate the MS signal but ironbearing paramagnetic minerals, such as olivine and many others, also contribute to MS. MS was measured with a susceptometer operating at $600 \mathrm{~Hz}$ and at an induction of 0.1 milliTesla (mT). Isothermal remanent magnetization (IRM) provides another measure of magnetic mineral content. IRMs were imparted in a forward induction of $1.2 \mathrm{~T}\left(\mathrm{IRM}_{1.2}\right)$ and a backfield (oppositely directed induction) of $0.3 \mathrm{~T}\left(\mathrm{IRM}_{0.3}\right)$ in an impulse magnetizer and were measured using a $90-\mathrm{Hz}$ spinner magnetometer with a sensitivity of $\sim 10^{-5} \mathrm{~A} \mathrm{~m}^{-1}$. Magnetite saturates below $0.3 \mathrm{~T}$, so that IRM at $0.3 \mathrm{~T}$ (herein designated IRM) is an appropriate measure of the amount of magnetite. The difference in IRM between 0.3 and $1.2 \mathrm{~T}$ is caused largely by hematite and is conventionally expressed as "hard" IRM or HIRM ((IRM $\left.\left.{ }_{1.2}-\mathrm{IRM}_{0.3}\right) / 2\right)$. The ratio, $\mathrm{IRM}_{0.3} / \mathrm{IRM}_{1.2}$, called the $S$ parameter, is a measure of the relative proportion of magnetite to all oxides, including hematite. High $S$ values indicate large amounts of magnetite relative to hematite (a maximum value of 1) and decreasing values indicate increasing amounts of hematite. Information about the domain state of magnetite (magnetic grain size) may be obtained from the magnitude of anhysteretic remanent magnetization (ARM) normalized by magnetite content from MS. ARM was imparted in a direct current induction of $0.1 \mathrm{mT}$ in the presence of a decaying alternating induction from 100 to $0 \mathrm{mT}$. The ratio ARM/MS increases as magnetic grain size decreases and is particularly sensitive to single domain (SD) and small pseudo-single domain (PSD) grain sizes.

\section{Results}

\subsection{Nearshore trapped sediment}

\subsubsection{Mid-summer sediment characteristics in time-series traps,} June 15-August 2, 2006

Sediment collection rates averaged $55 \pm 20 \mathrm{~g} \mathrm{~m}^{-2} \mathrm{day}^{-1}(1 \sigma)$ in Trap W during the two relatively quiescent months preceding the 
summer flood (Fig. 3a). Sediment collection rates were not significantly different in Trap SC but were slightly more variable $\left(1 \sigma=49 \mathrm{~g} \mathrm{~m}^{-2}\right.$ day $\left.^{-1}\right)$. The proportion of fine sediment collected in time-series traps increased with the exception of material collected on July 13. Material in Trap $\mathrm{W}$ had an average composition of $85 \pm 8 \mathrm{wt} \%$ fines while that in Trap SC was slightly coarser, $82 \pm 7$ wt\% fines (Fig. 3b). Fine sediment in Trap W averaged $16 \pm 4 \mathrm{wt} \% \mathrm{CaCO}_{3}$ and $3.7 \pm 0.3 \mathrm{wt} \% \mathrm{TOC}$, while fines in Trap SC had almost 2-fold higher $\mathrm{CaCO}_{3}, 31 \pm$ wt $3 \%$, with less organic $\mathrm{C}$, $2.4 \pm 0.3 \mathrm{wt} \%$ TOC (Figs. 3c,d). Material collected in Trap W just prior to the August flood had a high proportion of magnetite relative to hematite $(S=0.964)$, and the magnetite had relatively small domain sizes $\left(\mathrm{ARM} / \mathrm{MS}>500 \mathrm{~A} \mathrm{~m}^{-1}\right.$ ) (Table 2). Al-normalized Ba values were the same in Traps $\mathrm{W}$ and SC prior to the flood and varied little, averaging $8.5 \pm 0.3 \times 10^{-5}$ (Fig. 3e). Al-normalized Co values were also similar in both traps, averaging $6.2 \pm 0.4 \times 10^{-5}$, but decreased slightly through early August (Fig. 3f).

Prior to the summer flood similar ${ }^{7} \mathrm{Be}$ fluxes were measured in the two time-series sediment traps; however, material collected in
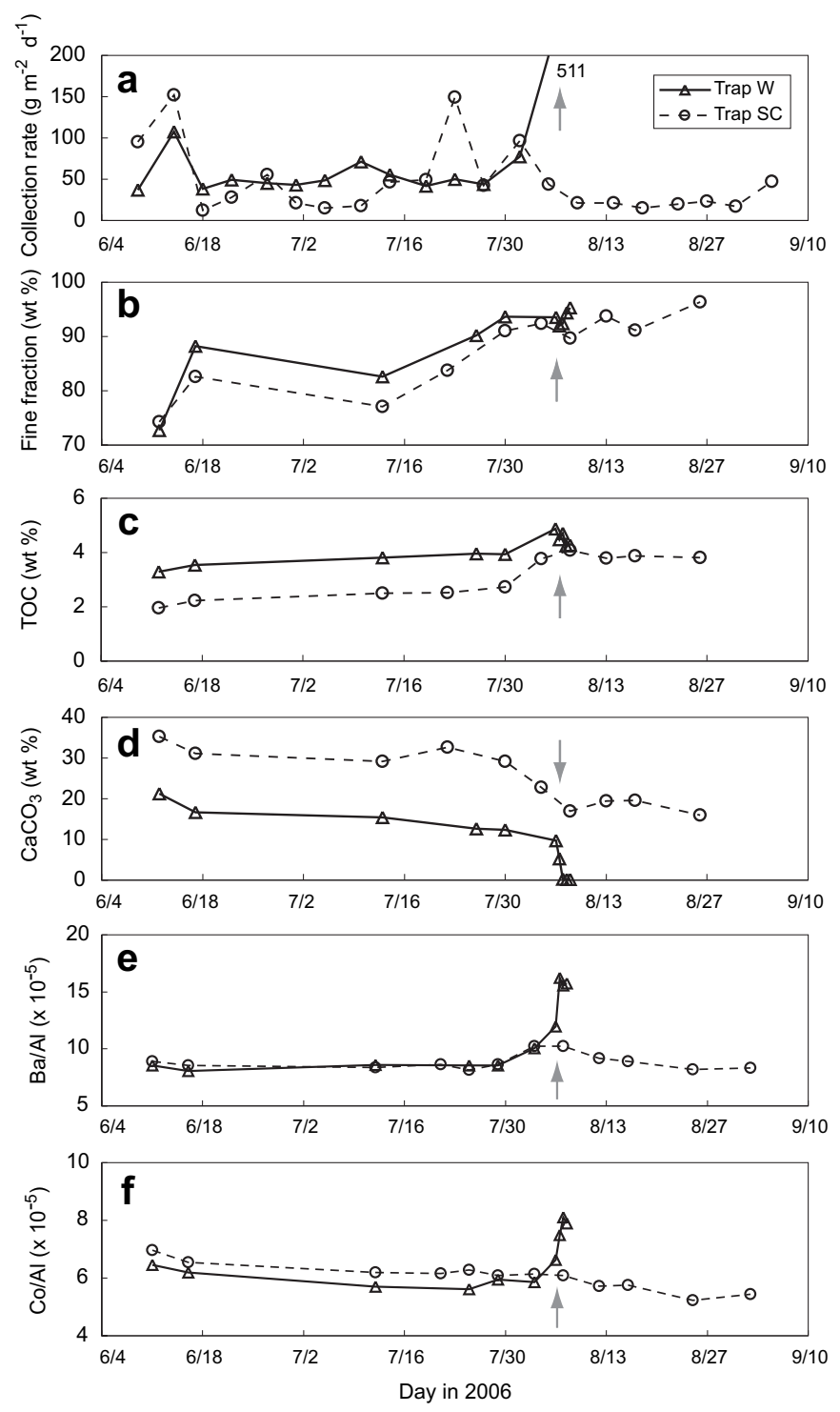

Fig. 3. Sediment properties in time-series sediment traps. (a) Collection rate; (b) fine fraction; (c) total organic carbon; (d) carbonate content; (e) Ba/Al ratio; and (f) $\mathrm{Co} / \mathrm{Al}$ ratio. Arrows show the August 6-7 flood. Data are plotted at mid-points of 4.5-day collection intervals.
Trap W near Hanalei River had an average ${ }^{7}$ Be activity twice as high as that in Trap SC (Figs. 4a-d). The average ${ }^{137}$ Cs flux measured in Trap W was almost three times as high as in Trap SC, and the material in Trap $\mathrm{W}$ had average ${ }^{137} \mathrm{Cs}$ activities over five times higher (Figs. $4 \mathrm{a}-\mathrm{d}$ ). In contrast, the average ${ }^{210} \mathrm{~Pb}$ flux measured in Trap SC was over $50 \%$ higher than that measured in Trap W, and the ${ }^{210} \mathrm{~Pb}$ activity of this material was also higher than that of material collected in Trap $\mathrm{W}$ (Figs. $4 \mathrm{a}-\mathrm{d}$ ). ${ }^{7} \mathrm{Be} /{ }^{210} \mathrm{~Pb}$ ratios were higher in Trap W than Trap SC (Fig. 4e), reflecting both the high terrestrial source of ${ }^{7} \mathrm{Be}$ and the relatively low terrestrial source of ${ }^{210} \mathrm{~Pb}$.

\subsubsection{Flood and post-flood sediment characteristics in time-series traps, August 2006}

Bottle 14 of Trap W (14W) opened on August 4, overfilled during the August 6-7 flood and rotated closed at the end of the day on August 7. Flood debris clogged the funnel apparatus and as a result bottles $15 \mathrm{~W}-21 \mathrm{~W}$ were recovered empty. The sediment collection rate was at least $511 \mathrm{~g} \mathrm{~m}^{-2}$ day $^{-1}$, ten times higher than the preflood average. Bulk sediment in the uppermost $15 \mathrm{~cm}$ of bottle $14 \mathrm{~W}$ contained only $0.2 \mathrm{wt} \% \mathrm{CaCO}_{3}$ (Fig. 3d), an indication that this layer was almost entirely terrigenous. This material will henceforth be referred to as 'flood sediment'. Flood sediment had a higher percentage of fines, $95 \% \mathrm{wt}$, and TOC, $4.3 \mathrm{wt} \%$, than pre-flood trapped material (Figs. 3b,c). Concentrations of magnetite (MS, IRM) and hematite (HIRM) increased during the flood (Table 2). Increases in magnetite corresponded approximately with decreased dilution of terrigenous material during the flood, but the $>50 \%$ increase in flood sediment HIRM apparently represented additional hematite in flood sediment. The differing degrees of Feoxide changes are consistent with the slight decrease in the $S$ parameter. The $18 \%$ decrease in ARM/MS in flood sediment compared with pre-flood sediment represents a slight increase in magnetic grain (domain) size that could represent a change in sediment provenance or a temporary increase in energy available to transport relatively high-density minerals. Al-normalized $\mathrm{Ba}$ and Co values in flood sediment were 86 and 32\% higher, respectively, than in pre-flood sediment (Figs. 3e,f). Metals associated with anthropogenic activities were elevated in flood sediment: $\mathrm{Cu}$ (292 ppm), Ni (454 ppm), Zn (206 ppm), and Pb (38 ppm), and were probably derived from non-point source stormwater runoff from roads bordering the river and the town of Hanalei. $\mathrm{Cu}$ and $\mathrm{Ni}$ concentrations exceeded levels where adverse biological impacts frequently occur (Long and Morgan, 1990). Sediment quality standards apply to bulk sediment (all grain sizes), whereas Hanalei sedimentary trace metals were measured in the fine fraction. Even allowing for dilution by larger particles, however, flood sediment $\mathrm{Cu}$ and $\mathrm{Ni}$ levels would still have exceeded levels of concern because the fine fraction comprised $95 \%$ of bulk material. Activities of ${ }^{7} \mathrm{Be}$ and ${ }^{137} \mathrm{Cs}$ in flood sediment increased to 15.8 and $1.0 \mathrm{dpm}$ $\mathrm{g}^{-1}$, respectively, and ${ }^{210} \mathrm{~Pb}$ activity decreased to $10.6 \mathrm{dpm} \mathrm{g} \mathrm{g}^{-1}$ (Fig. 4a). Radioisotope fluxes and the ratio of ${ }^{7} \mathrm{Be} /{ }^{210} \mathrm{~Pb}$ increased markedly in flood sediment (Figs. 4c,e): ${ }^{7} \mathrm{Be}$ (11-fold increase), ${ }^{137} \mathrm{Cs}$ (9-fold increase), ${ }^{210} \mathrm{~Pb}$ (3-fold increase), ${ }^{7} \mathrm{Be} /{ }^{210} \mathrm{~Pb}$ ratio (8-fold increase).

Table 2

Magnetic parameters in sediment collected offshore of the river mouth in rotating Trap W.

\begin{tabular}{cccccc}
\hline & $\begin{array}{l}\mathrm{MS} \times 10^{6} \\
\left(\mathrm{~m}^{3} \mathrm{~kg}^{-1}\right)\end{array}$ & $\begin{array}{l}\text { IRM } \\
\left(\mathrm{A} \mathrm{m}^{2} \mathrm{~kg}^{-1}\right)\end{array}$ & $\begin{array}{l}\mathrm{HIRM} \times 10^{3} \\
\left(\mathrm{~A} \mathrm{~m}^{2} \mathrm{~kg}^{-1}\right)\end{array}$ & $\begin{array}{l}\text { ARM/MS } \\
\left(\mathrm{A} \mathrm{m}^{-1}\right)^{*}\end{array}$ & $S$ parameter* \\
\hline $\begin{array}{c}\text { Pre-flood } \\
\text { sediment }\end{array}$ & 4.6 & 0.09 & 1.8 & 583 & 0.964 \\
$\begin{array}{c}\text { Flood } \\
\text { sediment } \\
\% \text { increase }\end{array}$ & 13.7 & 13.50 & 53.7 & -18 & -1.293 \\
\hline
\end{tabular}

*Concentration-independent. 

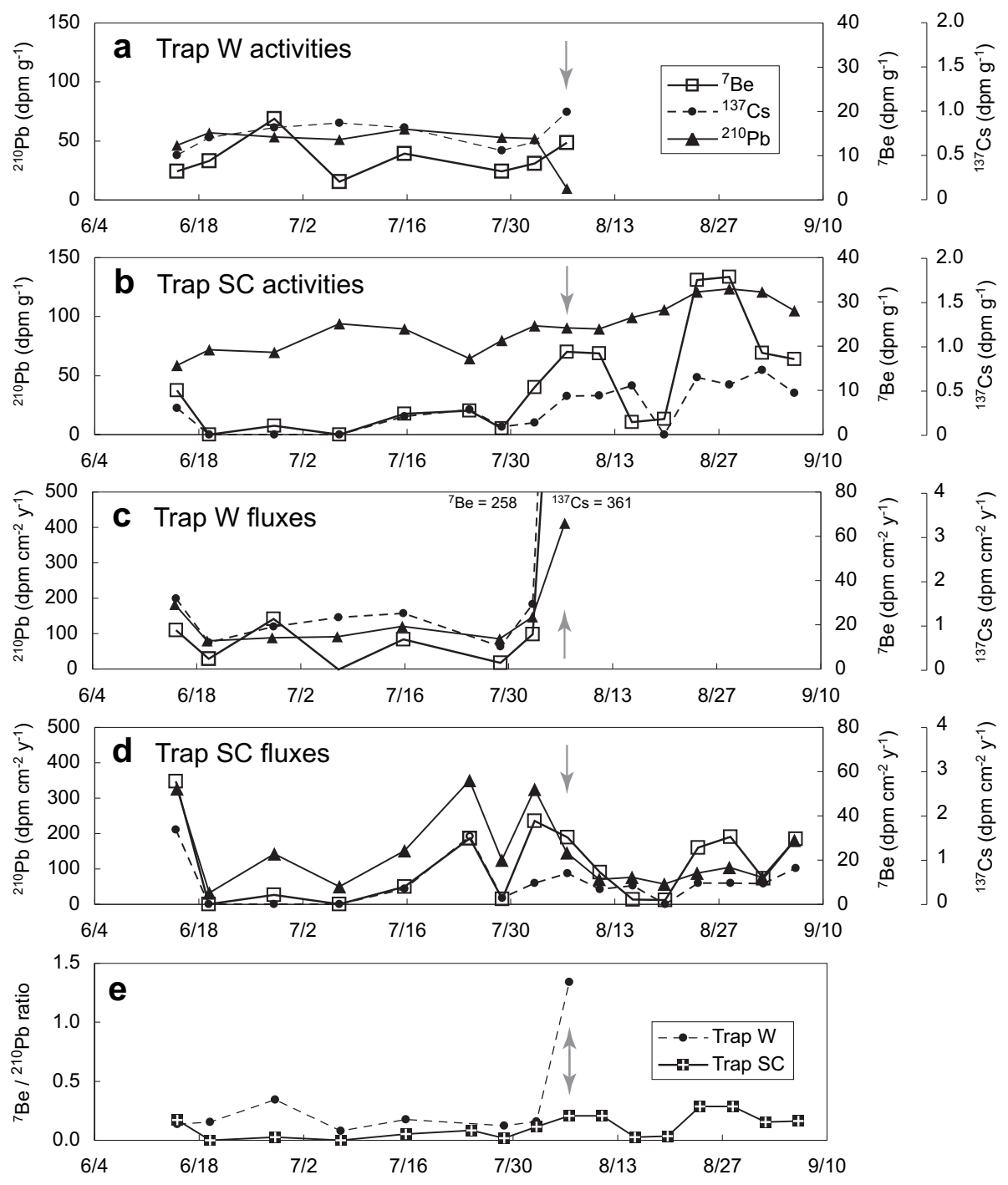

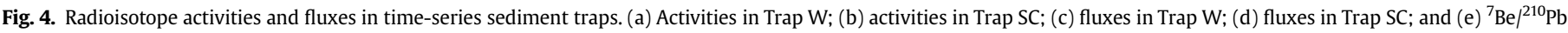
ratio. Arrows show the August 6-7 flood. Data are plotted at mid-points of 4.5-day collection intervals.

Sediment collection rates in Trap SC did not increase at the time of the flood (Fig. 3a); however, carbonate content decreased to 17\% during the flood and remained at lower values thereafter (Fig. 3d). The average fine fraction and TOC composition of material collected in August were higher than in June and July (Figs. 3b,c). These findings suggest that less resuspended carbonate sediment accumulated in Trap SC during and after the flood. There was a modest but statistically significant $13 \%$ increase in Al-normalized Ba values in Trap SC during and 1 week after the flood (Fig. 3e). Following the flood, ${ }^{7} \mathrm{Be}$ and ${ }^{137} \mathrm{Cs}$ activities and fluxes of material in Trap SC were higher and more variable than in preceding months (Figs. 4b,d). In contrast, ${ }^{210} \mathrm{~Pb}$ fluxes were generally lower and less variable than in June and July while ${ }^{210} \mathrm{~Pb}$ activities of material collected in Trap SC were higher (Figs. 4b,d). Sediment in Trap SC had the highest ${ }^{210} \mathrm{~Pb}$ activities among Hanalei Bay and the lower watershed. Magnetic parameters were not measured on Trap SC material.

\subsubsection{Spatial variations of sediment characteristics in tube traps}

Many sediment properties varied as a function of distance from the river mouth. Percent fines and TOC generally decreased (Fig. 5a), whereas the carbonate content of bulk and fine sediment increased with distance from the river (Fig. 5b). At the site least influenced by the Hanalei River (OR-T), trapped sediment was $88.7 \mathrm{wt} \%$ sand-sized carbonate; non-calcareous fine sediment only accounted for $1.5 \mathrm{wt} \%$ of the bulk material. Absolute concentrations of $\mathrm{Ba}$ and $\mathrm{Co}$ (Fig. 5c) and $\mathrm{Al}$ (not shown) decreased away from the river, consistent with their terrestrial origin. Al-normalized Ba values were on average $26 \%$ higher in traps near the river mouth than further away, but Al-normalized Co values did not vary (Fig. 5d). Like other terrigenous tracers, absolute concentration of magnetite and hematite (IRM and HIRM, respectively) and magnetic susceptibility (MS) decreased with distance from the Hanalei River (Fig. 5e). Magnetic domain size (ARM/MS) differed little (Fig. 5f) with much smaller variations than found in historical sediment deposits in the Black Hole in Hanalei Bay (ARM/MS between 237 and 598; Draut et al., 2009). The abundance of magnetite relative to hematite $(S)$ also varied little with distance from the river (Fig. 5f). There were no clear spatial patterns among radioisotope fluxes measured in tube traps (Figs. 5g,h). Radioisotope fluxes and mass accumulation rates in tube traps were significantly higher than in time-series traps because tube trap openings were closer to the seafloor where the suspended particle concentration due to resuspension is greatest. The ${ }^{7} \mathrm{Be} /{ }^{210} \mathrm{~Pb}$ ratio decreased with distance from Hanalei River (Fig. 5h). 

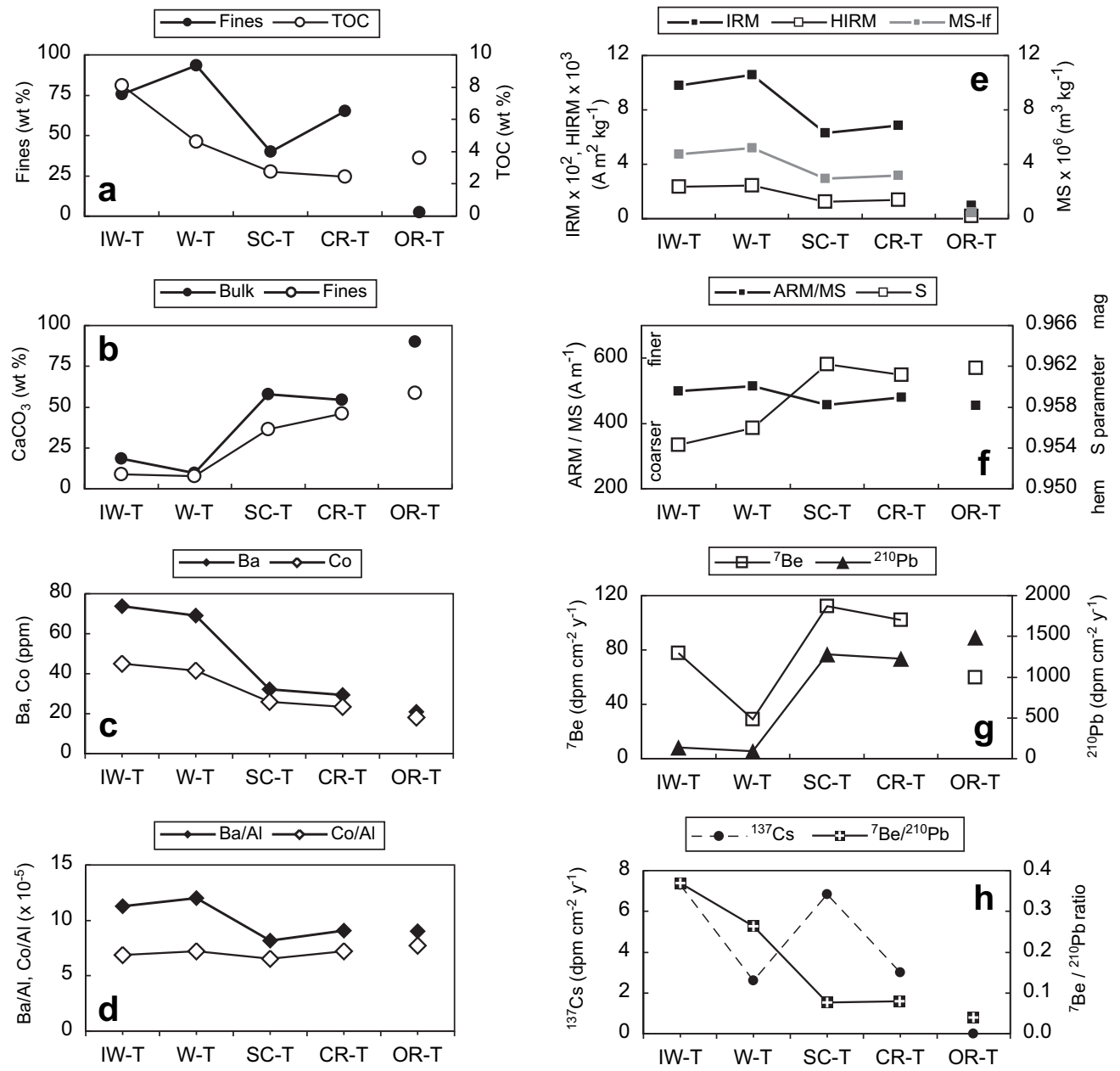

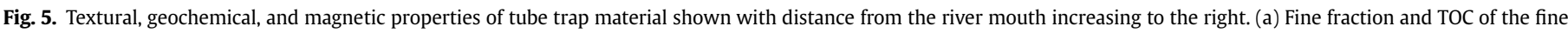

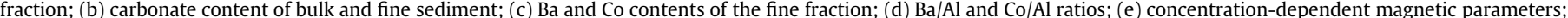

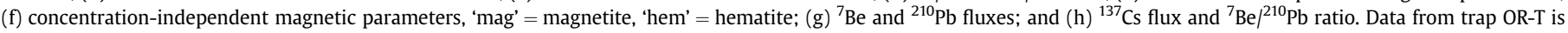
plotted separately because this site is outside of Hanalei Bay.

\subsection{Terrestrial soil and sediment characteristics}

Soil from a hillside roadcut (M12) was enriched in quartz and elements associated with aeolian inputs (Zieman et al., 1995) compared to average Hanalei soil (averages calculated from M1 to M11, M15, M16): Al (30\% higher), K (2-fold higher), Ti and V (3-fold higher), As (7-fold higher) and Th (10-fold higher). Based on Th contents over five times higher than average Hanalei soil, soil at M13 and M14, collected near the roadcut, appear to have mixed with aeolian material. Samples M12-M14 will be excluded from further discussion due to apparent allochthonous influences on their chemical compositions.

Although grain size distributions were not measured in all upland samples, values from select samples give a general idea of variations among depositional environments. There was a downstream decrease in sediment grain size distribution. Sediment grain size was coarsest in upland streambanks ( $38 \pm 9 \%$ fines; measured in M3, M6, M7), intermediate in floodplain streambanks and grassland (65 $\pm 3 \%$ fines; measured in M9A, M16) and finest in cultivated taro fields ( $83 \pm 10 \%$ fines; measured in M1A, M2, M11) and river suspended sediment (86\% fines; measured in RSS). The sand, silt, and clay composition of RSS was nearly identical to that of material deposited August 4-7 in sediment trap bottle-14W offshore of the river mouth.
Magnetic grain size was finest in RSS and coarser in terrestrial soil and sediment deposits (Fig. 6a). The magnetic grain size of flood sediment, ARM/MS $=465 \mathrm{~A} \mathrm{~m}^{-1}$, most closely resembled that in cultivated fields at sites M1, M2, M10, and M11, and in a floodplain riverbank (M15). However, it is not possible to distinguish from magnetic grain size alone whether an initially-coarser magnetic assemblage from further upstream was sorted while in transport to the nearshore sediment trap. Magnetic grain size increased slightly between pre-flood and flood sediment, perhaps reflecting higher hydraulic energy during the flood. The relative proportion of magnetite to hematite in RSS and flood sediment was intermediate $(S=0.95)$ among those of terrestrial environments $(0.92>S>0.99)$ excluding upland forest soil (M8), which had a distinctly lower magnetite concentration and $S$ of about 0.85 (Fig. 6a). The relatively high proportion of hematite (very low $S$ parameter values) in forest soil may be related to increased oxidation of magnetite to hematite during long-term weathering of bedrock. Sediment trapped on a grass-covered floodplain (M9) where agricultural runoff occurs during high-stage floods had $S$ values between 0.94 and 0.96 , very close to those of RSS and flood sediment. Sediment from the cultivated fields were slightly more hematite-rich, having $S$ values $0.92-0.94$. The highest $S$ values and lowest ARM/MS values come from riverbank deposits mostly composed of relatively coarse-grained fluvial sediment that would 

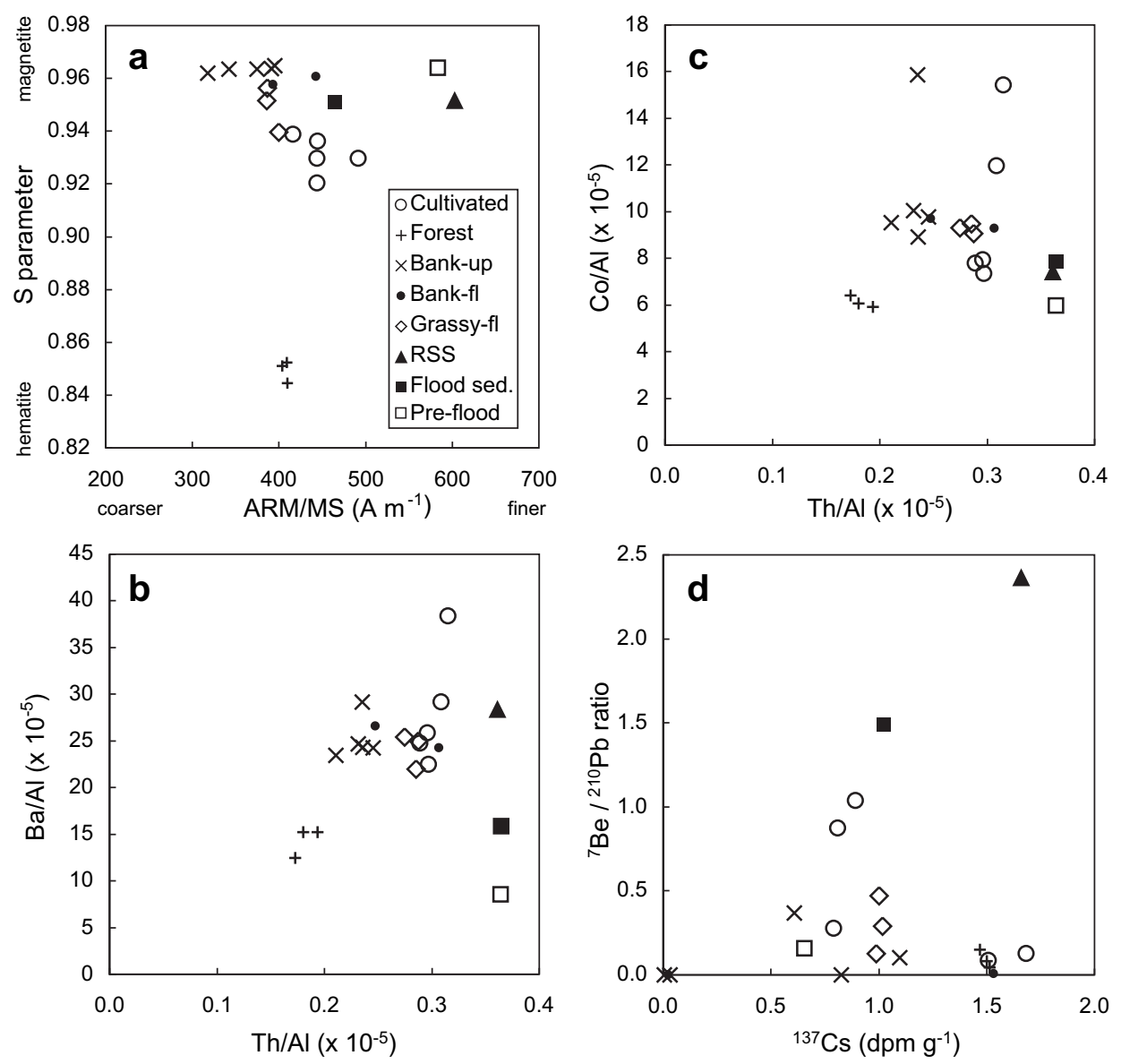

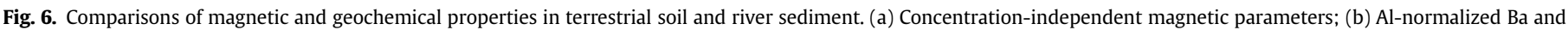

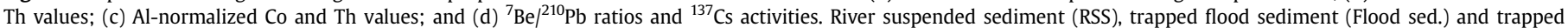
sediment collected in June and July (Pre-flood) from station W are shown for comparison. 'up' = upland, 'fl' = floodplain.

be expected to contain basaltic rock fragments in which magnetite has been protected from oxidation. These conditions would favor both the observed relatively high $S$ values and low ARM/MS values.

Al-normalized $\mathrm{Ba}$ and $\mathrm{Co}$ values plotted as a function of Alnormalized Th show that similar sedimentary environments generally cluster near each other along the Th/Al axis (Figs. 6b,c). The $\mathrm{Ba} / \mathrm{Al}$ value of RSS was higher than those of all but one terrestrial environment, resembling most closely that of cultivated field M1 and upland riverbank M7. The Ba/Al ratio of flood sediment was lower than all terrestrial soil or sediment except upland forest soil. The $\mathrm{Co} / \mathrm{Al}$ ratios of RSS and flood sediment were indistinguishable within the analytical uncertainty. Cultivated fields M2, M10, and M11 had Al-normalized Co values that were the most similar to RSS and flood sediment. The remaining terrestrial environments had higher $\mathrm{Co} / \mathrm{Al}$ values than RSS and flood sediment, except the upland forest.

Ratios of ${ }^{7} \mathrm{Be} /{ }^{210} \mathrm{~Pb}$, as well as their specific activities, were higher in RSS and flood sediment than in any sampled terrestrial environment (Fig. 6d). The elevated ${ }^{7} \mathrm{Be} /{ }^{210} \mathrm{~Pb}$ ratio in RSS was entirely due to its higher ${ }^{7} \mathrm{Be}$ activity. Cultivated field M1 had the highest ${ }^{7} \mathrm{Be} /{ }^{210} \mathrm{~Pb}$ ratio and a ${ }^{137} \mathrm{Cs}$ activity somewhat lower than that of flood sediment. Only two of seven riverbanks had detectable ${ }^{7} \mathrm{Be} /{ }^{210} \mathrm{~Pb}$ ratios (M4, M7), reflecting the isolation of subsurface soil from atmospheric-fallout. Sediment trapped offshore of the river mouth in June and July (pre-flood) had a significantly lower ${ }^{137} \mathrm{Cs}$ activity than flood sediment, and was in the lower end of the range of terrestrial soil or sediment.

\section{Discussion}

5.1. Nearshore sediment end member compositions and mixing relations

There are two types of sediment in Hanalei Bay: sand-sized and finer particles derived from calcium carbonate secreted by marine organisms and terrestrial soil weathered from basalt (Kennedy et al., 1998; Chadwick et al., 2003) containing small amounts of organic matter. Trapped sediment was a mixture of these end members. Sample processing protocols did not allow extraction of the carbonate fraction, so the best approximation of the geochemical properties of this end member comes from pre-flood material collected in the sediment trap outside of Hanalei Bay away from terrestrial inputs. The bulk material was composed of $91 \%$ sand-sized particles, had $\mathrm{TOC}=0.7 \%$, near-zero ${ }^{7} \mathrm{Be}$ and ${ }^{137} \mathrm{Cs}$ activities, and ${ }^{210} \mathrm{~Pb} \sim 5 \mathrm{dpm} \mathrm{g}^{-1}$. Such low ${ }^{7} \mathrm{Be}$ and ${ }^{137} \mathrm{Cs}$ activities are consistent with coarse-grained material eroded from a submerged reef. Although radioisotopic activities were low, the mass accumulation rate in the sediment trap outside the bay was extremely high (five to 22 times higher than in traps inside the bay), resulting in high ${ }^{7} \mathrm{Be}$ and ${ }^{210} \mathrm{~Pb}$ fluxes over the study period.

Linear regressions of radioisotope activities against carbonate content of the fine fraction in sediment traps show mixing relations between terrestrial and carbonate end members (Fig. 7). Sediment collected near the mouth of Hanalei River was a mixture of ${ }^{7} \mathrm{Be}-$ enriched terrestrial sediment $\left(\mathrm{CaCO}_{3} \sim 0 \%\right)$ and ${ }^{7} \mathrm{Be}$-depleted carbonate sediment (Fig. 7a). This relation did not hold for 
sediment in south-central Hanalei Bay, however, indicating that there were other ${ }^{7} \mathrm{Be}$ sources at this site. Non-zero ${ }^{137} \mathrm{Cs}$ activities of sediment trapped throughout the bay fell along a single regression, or mixing, line between ${ }^{137} \mathrm{Cs}$-enriched terrigenous sediment and ${ }^{137} \mathrm{Cs}$-depleted carbonate (Fig. 7b), indicating that, as expected, terrestrial sediment was the sole source of ${ }^{137} \mathrm{Cs}$ to Hanalei Bay. ${ }^{210} \mathrm{~Pb}$ activities of material collected near the river mouth were lowest in terrestrial sediment and increased with carbonate content (Fig. 7c), suggesting a marine source of ${ }^{210} \mathrm{~Pb}$. Higher ${ }^{210} \mathrm{~Pb}$ activities of material collected in south-central Hanalei Bay compared to the river mouth suggest that marine inputs of ${ }^{210} \mathrm{~Pb}$ were greater at this site.
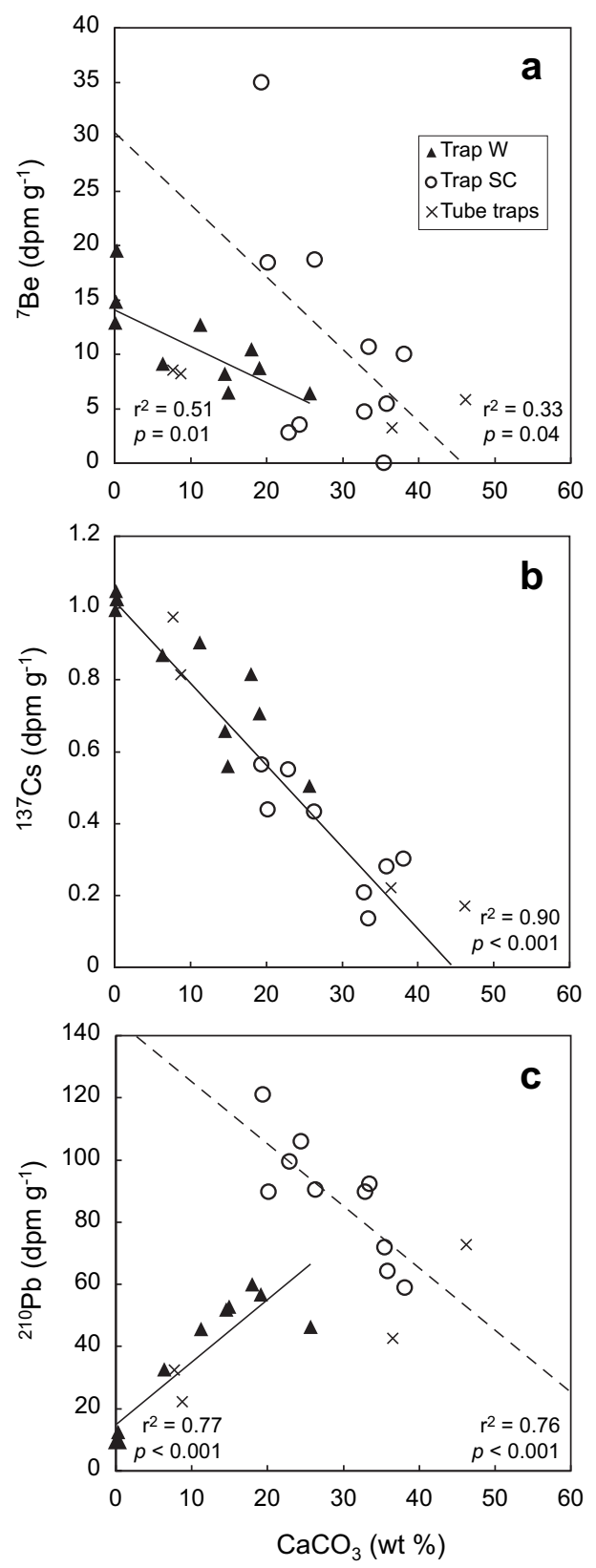

Fig. 7. Regressions of radioisotope activities in nearshore trapped sediment against carbonate contents of the fine fraction. (a) ${ }^{7} \mathrm{Be}$; (b) ${ }^{137} \mathrm{Cs}$; and (c) ${ }^{210} \mathrm{~Pb}$. Lines are leastsquares regression lines. Solid lines in $7 \mathrm{a}$ and $\mathrm{c}$ are regressions for Trap $\mathrm{W}$ time-series samples (triangles) plus tube traps W-T and IW-T $\left(\mathrm{CaCO}_{3} 8\right.$ and 9\%, respectively). Dashed lines in a and c are regressions for Trap SC time-series data (open circles) plus tube traps SC-T and CR-T. The regression line in b is for the composite data.

\subsection{Atmospheric and oceanic sources of ${ }^{210} \mathrm{~Pb}$ and ${ }^{7} \mathrm{Be}$}

The two other significant sources of ${ }^{210} \mathrm{~Pb}$ and ${ }^{7} \mathrm{Be}$ to coastal waters are direct atmospheric deposition and lateral advection of oceanic water. The annual atmospheric deposition of ${ }^{210} \mathrm{~Pb}$ and ${ }^{7} \mathrm{Be}$ to the surface of the bay is estimated to be 0.25 and $6 \mathrm{dpm} \mathrm{cm}^{-2}$ year $^{-1}$, respectively (Cochran et al., 1990; Liu et al., 2001; Koch et al., 1996). There may have been minor contributions from surface water runoff from Hanalei watershed, but these inputs were probably a small percentage of the atmospheric flux (1 and 5\%, respectively) based on work in other watersheds (Baskaran and Santschi, 1993; Olsen et al., 1989). In situ production of ${ }^{210} \mathrm{~Pb}$ within Hanalei Bay from the decay of dissolved ${ }^{226}$ Ra was assumed to be negligible due to the shallow water column (average depth $10 \mathrm{~m}$ ).

Dissolved ${ }^{210} \mathrm{~Pb}$ and ${ }^{7} \mathrm{Be}$ concentrations are generally higher in the open ocean than at the coast because particle concentrations are lower (Bruland et al., 1974; Nozaki et al., 1976; Olsen et al., 1989). When oceanic water is advected to the coast and encounters high suspended particle concentrations, ${ }^{210} \mathrm{~Pb}$ and ${ }^{7} \mathrm{Be}$ readily adsorb to particles due to their high particle affinities (Krishnaswami et al., 1973; Thomson and Turekian, 1976; Carpenter et al., 1981; Moore et al., 1981; Olsen et al., 1986; Olsen et al., 1989; Cochran et al., 1990). Bottom sediment resuspension by waves and currents in shallow coastal areas results in additional ${ }^{210} \mathrm{~Pb}$ and ${ }^{7} \mathrm{Be}$ scavenging onto resuspended particles (Olsen et al., 1989; Baskaran and Santschi, 1993; Jweda et al., 2008). The input of ${ }^{210} \mathrm{~Pb}$ to Hanalei Bay from Pacific water is $4.1 \times 10^{11} \mathrm{dpm}_{\text {year }}{ }^{-1}$ based on the surface water ${ }^{210} \mathrm{~Pb}$ concentration of $147 \mathrm{dpm} \mathrm{m}{ }^{-3}$ near Hawaii and an exchange of $7.6 \times 10^{6} \mathrm{~m}^{3}$ day $^{-1}$ for water in Hanalei Bay (C. Storlazzi, pers. comm.). This suggests a maximum oceanic ${ }^{210} \mathrm{~Pb}$ flux of $9.3 \mathrm{dpm} \mathrm{cm}{ }^{-2}$ year $^{-1}$ for a seafloor area of $4.4 \mathrm{~km}^{2}$ (Calhoun et al., 2002 ) if all dissolved ${ }^{210} \mathrm{~Pb}$ is scavenged and deposited. A similar calculation for ${ }^{7} \mathrm{Be}$ shows that the flux of oceanic ${ }^{7} \mathrm{Be}$ would be about $0.1 \mathrm{dpm} \mathrm{cm}{ }^{-2}$ year ${ }^{-1}$ using a ${ }^{7}$ Be concentration of $1.5 \mathrm{dpm}$ $\mathrm{m}^{-3}$ (Feichter et al., 1991).

A key observation is that the combined estimated atmospheric and the oceanic fluxes of these two isotopes can account for only about $7 \%$ of the ${ }^{210} \mathrm{~Pb}$ and $32 \%$ of the ${ }^{7} \mathrm{Be}$ average fluxes on an area basis measured in the Hanalei Bay time-series sediment traps during non-flood periods of summer 2006 (Figs. 4c,d). The large balance of isotope flux measured in the traps is interpreted as evidence of both frequent sediment resuspension and scavenging of the isotopes by suspended particles. During the 3 months study period alone there were 11 events (river mouth) and 15 events (south-central bay) when bottom shear stresses were strong enough to resuspend seafloor sediment (Draut et al., 2009; Storlazzi et al., 2009). This scavenging process is important because it influences the fate of any particle-reactive contaminant added to the coastal ocean from the land, atmosphere, or the marine realm. Examples of contaminants include heavy metals, polycyclic aromatic hydrocarbons, and legacy chemicals such as DDT and PCBs (Olsen et al., 1982). Such particle-pollutant affinities indicate that as sediment-loading from the watershed increases, contaminant exposure to reef communities could increase, particularly to filterfeeding organisms like coral.

\subsection{Salinity-dependent desorption of trace elements}

Ba delivered to estuaries and coasts is primarily adsorbed onto river suspended particles rather than in mineral lattices (Martin and Meybeck, 1979). In terrestrial and fluvial sediment, Al-normalized $\mathrm{Ba}$ values should reflect source rock composition because it is strongly adsorbed to clays. When fluvial particles encounter higherionic strength seawater mixtures, however, $\mathrm{Ba}$ is displaced from particulate binding sites and $\mathrm{Ba} / \mathrm{Al}$ ratios of river particles decrease 
while dissolved Ba concentrations increase (Edmond et al., 1978; Coffey et al., 1997). The Hanalei River, with an annual average discharge of $3.8 \mathrm{~m}^{3} \mathrm{~s}^{-1}$, is a low-flow river, and under these conditions Ba likely desorbs at intermediate salinity, 5-15 (salinity reported using the Practical Salinity Scale; Coffey et al., 1997). When discharge increases during floods, the low-salinity region expands across the coastal zone and Ba may desorb at lower salinity, typically less than 5 (Coffey et al., 1997). Ba-desorption under low-flow conditions in June and July 2006 could explain why Ba/Al ratios of nearshore trapped sediment were lower than all watershed soil or sediment values except in the upland forest. A lesser degree of Badesorption under flood conditions is consistent with the Ba peak in flood sediment. Thus, although there is a prominent flood signal in sediment trap $\mathrm{Ba} / \mathrm{Al}$ ratios, Ba-desorption in the coastal ocean appears to preclude its utilization as a quantitative geochemical fingerprinting tool in nearshore environments.

In contrast to $\mathrm{Ba}$, Co does not appear to have desorbed from river particles during freshwater-seawater mixing. Almost half of the Co transported in rivers to the coastal ocean is a crystalline phase and Co is not affected by ion-exchange in the estuarine mixing zone (Gibbs, 1977; Martin and Meybeck, 1979). The similarity of $\mathrm{Co} / \mathrm{Al}$ values in RSS and flood sediment and the similarity of average $\mathrm{Co} / \mathrm{Al}$ ratios in all five tube traps are evidence that Co concentrations are not salinity-dependent. In the absence of alteration during transport, Al-normalized Co values in sediment trapped in Hanalei Bay reflect those of terrestrial sources.

\subsection{Sources of terrigenous sediment}

When compared to Hawaiian basalt, the composition of terrestrial soil and sediment in the Hanalei watershed are generally intermediate between trace element-depleted tholeiitic basalt that forms the bulk of Kauai, and alkali basalt (Fig. 8) that is present in the eastern wall of Hanalei valley (Feigenson, 1984; Clague and

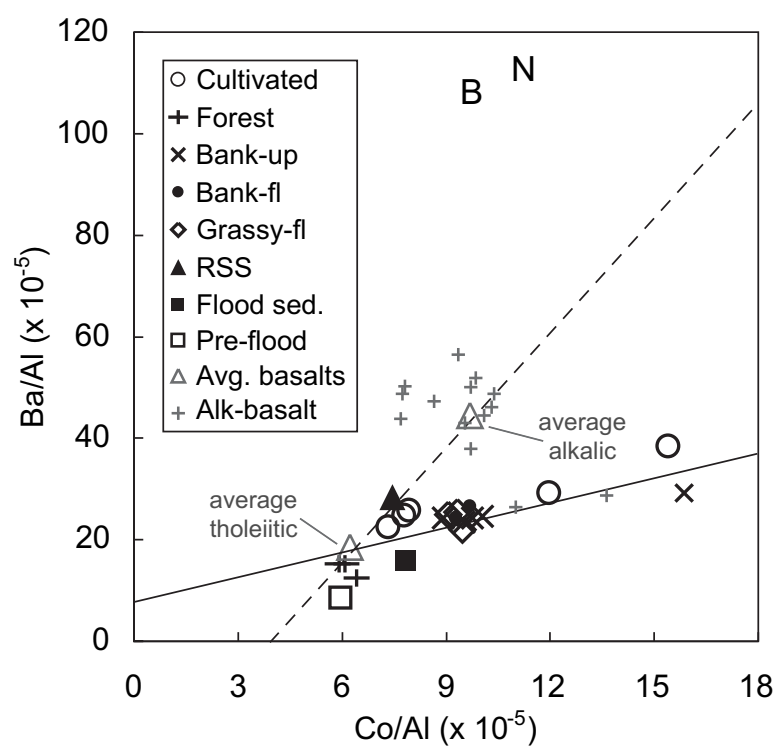

Fig. 8. Comparison of Al-normalized Ba and Co values of Hanalei soil and sediment with those of common basalt types (Basalts) on Kauai. The average tholeiitic basalt composition is from USGS rock standards BHVO-1 and BHVO-2. Compositions of fourteen alkali basalts (Alk-basalt) from Reiners and Nelson (1998), shown as the cloud of gray "+" signs, were averaged to get the average alkali basalt composition. The dashed line is a mixing line between average tholeiitic basalt and average alkali basalt. The solid line is a mixing line between average tholeiitic basalt and the two Co-rich alkali basalts. 'up' = upland, 'fl' = floodplain. "B" (basanite) and "N" (nephelinite), shown for comparison, are other types of basalt that outcrop near Hanalei watershed but do not appear to be parent rocks of Hanalei soil (see text).
Dalrymple, 1988; Reiners and Nelson, 1998). Two watershed sites, a taro field (M1) and an upland streambank (M7), have higher Co concentrations than the alkali basalts analyzed by Reiners and Nelson (1998), and fall close to a mixing line between tholeiitic basalt and the two Co-enriched alkali basalts (Fig. 8), suggesting that a Co-enriched alkali basalt end member remains to be identified. Two other types of basalt, basanite ("B" in Fig. 8) and nephelinite ("N" in Fig. 8) that outcrop near Hanalei watershed are shown for comparison, but did not appear to be parent rocks of Hanalei soil based on their high $\mathrm{Ba} / \mathrm{Al}$ ratios. The $\mathrm{Ba}$ and $\mathrm{Co}$ composition of forest soil (M8) was very similar to that of the tholeiitic basalt end member. This compositional similarity indicates a lack of mixing with sediment transported by the Hanalei River and perhaps explains why forest soil has distinct trace element and magnetic characteristics compared to other terrestrial environments.

In combination, Al-normalized $\mathrm{Co},{ }^{7} \mathrm{Be} /{ }^{210} \mathrm{~Pb}$ ratios, and magnetic grain size of flood sediment point to runoff from cultivated fields as the most likely source of sediment during moderate flood conditions in August. It is important to note, however, that our limited sampling along the river and valley allows for the possibility that there were other source regions in the watershed. Erosion of agricultural soil could have a greater impact on nearshore biotic communities than erosion of other sedimentary deposits because agricultural runoff is typically associated with elevated levels of contaminants such as nitrogen-based fertilizers and pesticides (FAO, 2003; Orazio et al., 2007). This is the case for Hanalei taro fields, which are fertilized at the end of summer. Stormwater runoff from roads bordering the river and the town of Hanalei probably contributed to elevated heavy metals in flood sediment. The sediment and contaminants delivered to Hanalei Bay may pose a greater threat to nearshore organisms in summer than in winter because calm summer oceanic conditions result in longer exposure times (Draut et al., 2009).

Radioisotope activities show that, in the absence of storms, suspended sediment in the Hanalei River may be mobilized from different regions of the watershed. Soil ${ }^{7}$ Be activity increases with precipitation and thus elevation (Wallbrink and Murray, 1996; Whiting et al., 2005). The 14 -fold higher ${ }^{7}$ Be activity of river suspended sediment collected in September compared to lower watershed soil indicates that this sediment originated higher in the watershed where orographic precipitation is frequent. Since ${ }^{7} \mathrm{Be}$ activities are highest in the surficial layer and attenuate to zero below a few $\mathrm{cm}$ in undisturbed soil, sediment with high ${ }^{7}$ Be activity must have been mobilized by overland flow. The relatively low

${ }^{137} \mathrm{Cs}$ and ${ }^{7} \mathrm{Be}$ activities of nearshore trapped sediment during June and July suggests that riverbank undercutting was another mechanism by which suspended sediment was supplied to the Hanalei River in dry periods (Hill et al., 1998). Relatively low pre-flood Co values (Figs. $3 \mathrm{f}$ and 8 ) further suggest that sediment runoff during June and July originated in soil weathered from tholeiitic basalt on the western slopes of Hanalei Valley.

\section{Conclusions}

Geochemical tracers in nearshore trapped sediment reflect the combined influences of terrestrial sediment composition and nearshore processes. Ba associated with land-derived sediment was affected by desorption during freshwater-seawater mixing and so was a qualitative rather than quantitative indicator of flood sediment deposition in the nearshore. ${ }^{7} \mathrm{Be}$ and ${ }^{210} \mathrm{~Pb}$ activities of suspended particles collected in south-central Hanalei Bay were probably affected by geochemical scavenging of dissolved radioisotopes supplied in oceanic water onto resuspended bottom sediment. Al-normalized Co values and ${ }^{137}$ Cs activities, however, 
appeared to be conserved over the short time and distance scales of transport from the Hanalei river mouth to nearshore sediment traps. In terrestrial soil and sediment, concentration-independent (grain size independent) properties: normalized trace element ratios, ${ }^{7} \mathrm{Be} /{ }^{210} \mathrm{~Pb}$ ratios, magnetic domain size and relative magnetite-hematite concentrations, should reflect sediment provenance.

A multi-tracer fingerprint indicates that at least some terrestrial runoff during a moderate flood on the Hanalei River in August 2006 came from farmland used for taro cultivation along the lower reach of the river. It is possible that there were other watershed sources of storm runoff that were not characterized because our sampling effort was limited to the lower watershed. Non-point source stormwater runoff from roads probably contributed to elevated $\mathrm{Ni}$, $\mathrm{Cu}, \mathrm{Zn}$, and $\mathrm{Pb}$ in flood sediment. Sediment and contaminant runoff to Hanalei Bay during summer floods may pose a greater threat to coral reef communities than in winter because sediment may persist for several months. During dry periods, the regions of the watershed supplying sediment to the Hanalei River varied. In June and July, low Co values and ${ }^{7} \mathrm{Be}$ and ${ }^{137} \mathrm{Cs}$ activities suggest that terrestrial runoff was mobilized by riverbank undercutting on the western side of the Hanalei Valley, while in September elevated ${ }^{7} \mathrm{Be}$ activities in river suspended sediment indicate that rainfall mobilized surficial soil in the upper watershed where ${ }^{7} \mathrm{Be}$ activities increase with annual rainfall and elevation.

\section{Acknowledgements}

The authors thank the following colleagues for their help with this research: Mike Field for leading the Coral Reef Project; Suzie Cochran and Amy Draut for the collection of nearshore sediment; Carl Berg for his help with field work and as our resident science advisor for the Hanalei watershed-reef system; Lea Zimmerman for help sieving samples; Rob Franks for help with ICP-MS trace element analyses; Harland Goldstein and Jiang Xiao for analysis of magnetic properties and grain size; Michael Casso for analysis of radioactive isotopes; Rick Rendigs for preparation and deployment/recovery of time-series traps; Kate McMullan for textural analysis; Steve Manganini for analysis of organic carbon and carbonate in trap samples; Pete Swarzenski, Dan Hoover, Mark Baskaran and an anonymous reviewer for constructive reviews of this manuscript.

\section{References}

Baker, E.T., Milburn, H.B., Tennant, D.A., 1988. Field assessment of sediment trap efficiency under varying flow conditions. Journal of Marine Research 46, $573-$ 592.

Baskaran, M., Santschi, P.H., 1993. The role of particles and colloids in the transport of radionuclides in coastal environments of Texas. Marine Chemistry 42, 95-114.

Bellwood, D.R., Hughes, T.R., Folke, C., Nyström, M., 2004. Confronting the coral reef crisis. Nature 429, 827-833.

Bothner, M.H., Baldwin, S.M., Casso, M.A., Draut, A.E., Rendings, R., Reynolds, R.L. Takesue, R.K., 2007. Tracing mobile sediments in the Hanalei watershed and bay system: a geochemical approach. In: Field, M.E., Berg, C.J., Cochran, S.A. (Eds.), Science and Management in the Hanalei Watershed: A Trans-Disciplinary Approach. USGS Open File Report2007-1219, pp. 5-9.

Brown, E.K., Friedlander, A., 2007. Spatio-temporal patterns in coral cover and coral settlement on an exposed shoreline in Hawaii. In: Field, M.E., Berg, C.J., Cochran, S.A. (Eds.), Science and Management in the Hanalei Watershed: A TransDisciplinary Approach. USGS Open File Report2007-1219. pp. 10-12.

Bruland, K.W., Kiode, M., Goldberg, E.D., 1974. The comparative marine geochemistries of lead 210 and radium 226. Journal of Geophysical Research 79, 3083-3086.

Calhoun, R.S., Fletcher, C.H., 1996. Late Holocene coastal plain stratigraphy and sea-level history at Hanalei, Kauai, Hawaiian Islands. Quaternary Research 45, 47-48.

Calhoun, R.S., Fletcher, C.H., 1999. Measured and predicted sediment yield from a subtropical, heavy rainfall steep-sided river basin: Hanalei, Kauai, Hawaiian Islands. Geomorphology 30, 213-226.
Calhoun, R.S., Fletcher, C.H., Harney, J.N., 2002. A budget of marine and terrestrial sediments, Hanalei Bay, Kauai, Hawaiian Islands. Sedimentary Geology 150, 61-87.

Carpenter, R., Bennett, J.T., Peterson, M.L., 1981. ${ }^{210} \mathrm{~Pb}$ activities in and fluxes to sediments of the Washington continental slope and shelf. Geochimica et Cosmochimica Acta 45, 1155-1172.

Chadwick, O.A., Gavenda, R.T., Kelly, E.F., Ziegler, K., Olson, C.G., W.C., E., Hendricks, D.M., 2003. The impact of climate on the biogeochemical functioning of volcanic soils. Chemical Geology 202, 195-233.

Clague, D.A., Dalrymple, G.B., 1988. Age and petrology of alkalic postshield and rejuvenated-stage lava from Kauai, Hawaii. Contributions to Mineralogy and Petrology 99, 202-218.

Cochran, J.K., McKibbin-Vaughan, T., Dornblaser, M.M., Hirschberg, D Livingston, H.D., Buesseler, K.O., $1990 .{ }^{210} \mathrm{~Pb}$ scavenging in the North Atlantic and North Pacific Oceans. Earth and Planetary Science Letters 97, 332-352.

Cochran, S.A., Field, M.E., Storlazzi, C.D., 2007. Distribution of mud in Hanalei Bay, Kauai: June vs. September 2006. In: Field, M.E., Berg, C.J., Cochran, S.A. (Eds.) Science and Management in the Hanalei Watershed: A Trans-Disciplinary Approach. USGS Open File Report2007-1219. pp. 18-21.

Coffey, M., Dehairs, F., Collette, O., Luther, G., Church, T., Jickells, T., 1997. The behavior of dissolved barium in estuaries. Estuarine, Coastal and Shelf Science 45, 113-121.

Condie, K.C., 1993. Chemical composition and evolution of the upper continental crust: contrasting results from surface samples and shales. Chemical Geology $104,1-37$.

Cutshall, N.H., Larsen, I.L., Olsen, C.R., 1983. Direct analyses of ${ }^{210} \mathrm{~Pb}$ in sediment samples: self-absorption corrections. Nuclear Instruments and Methods in Physics Research. Section A 206, 309-312.

Draut, A.E., Field, M.E, Bothner, M.H., Logan, J.B., Casso, M.A., Baldwin, S.M., Storlazzi, C.D., 2006. Coastal circulation and sediment dynamics in Hanalei Bay, Kauai, Hawaii, Part II: tracking recent fluvial sedimentation; isotope stratigraphy obtained in summer 2005. U.S. Geological Survey Open File Report 20071125, http://pubs.usgs.gov/of/2006/1125, 52 pp.

Draut, A.E., Bothner, M.H., Field, M.E., Reynolds, R.L., Cochran, S.A., Logan, J.B., Storlazzi, C.D., Berg, C.J., 2009. Supply and dispersal of flood sediment from a steep, tropical watershed: Hanalei Bay, Kauai, Hawaii. USA. Geological Society of America Bulletin 121, 574-585.

Edmond, J.M., Boyle, E.D., Drummond, D., Grant, B., Mislick, T., 1978. Desorption of barium in the plume of the Zaire (Congo) river. Netherlands Journal of Sea Research 12, 324-328.

EPA, 2008. TMDL report for Hanalei Bay Watershed. http://iaspub.epa.gov/tmdl waters10/attains_impaired_waters.tmdl_report?p_tmdl_id=352948p_tribe $=$.

Fabricius, K.E., 2005. Effects of terrestrial runoff on the ecology of corals and cora reefs: review and synthesis. Marine Pollution Bulletin 50,125-146.

FAO, 2003. Agriculture and the environment: changing pressures, solutions and trade-offs. In: Bruinsma, J. (Ed.), World Agriculture: Towards 2015/2030, an FAO Perspective. Earthscan Publications Ltd, London, pp. 331-356.

Feichter, J., Brost, R.A., Heimann, M., 1991. Three-dimensional modeling of the concentration and deposition of ${ }^{210} \mathrm{~Pb}$ aerosols. Journal of Geophysical Research 96, 22,447-22,460.

Feigenson, M.D., 1984. Geochemistry of Kauai volcanics and a mixing model for the origin of Hawaiian alkalai basalts. Contributions to Mineralogy and Petrology 87, 109-119.

Fralick, P.W., Kronberg, B.I., 1997. Geochemical discrimination of clastic sedimentary rock sources. Sedimentary Geology 113, 111-124.

Garcia-Agudo, E., 1998. Global Distribution of ${ }^{137}$ Cs Inputs for Soil Erosion and Sedimentation Studies. Proceedingsof a Consultants Meeting on the use of ${ }^{137} \mathrm{Cs}$ in the Study of Soil Erosion and Sedimentation, 13-16 November 1995, Vienna, Austria. International Atomic Energy Agency, pp. 117-121.

Gardner, T.A., Cote, I.M., Gill, J.A., Grant, A., Watkinson, A.R., 2003. Long-term region-wide declines in Caribbean corals. Science 301, 958-960.

Gibbs, R., 1977. Transport phases of transition metals in the Amazon and Yukon Rivers. Geological Society of America Bulletin 88, 829-843.

Hill, B.A., DeCarlo, E.H., Fuller, C.C., Wong, M.F., 1998. Using sediment 'fingerprints' to assess sediment-budget errors, North Halawa Valley, Oahu, Hawaii, 1991-92. Earth Surface Processes and Landforms 23, 493-508.

Ivanovich, M., Latham, A.G., Ku, T.-L., 1992. Uranium-series disequilibrium applications in geochronology. In: Ivanovich, M., Harmon, R.S. (Eds.), Uranium-series Disequilibrium: Applications to Earth, Marine, and Environmental Sciences. Oxford University Press, Oxford, pp. 62-94.

Jackson, JB.C. Kirby, MX, Berger, W.H., Bjorndal, K. A, Botsford, LW, Bourque, BJ. Bradbury, R.H., Cooke, R., Erlandson, J., Estes, J.A., Hughes, T.P., Kidwell, S. Lange, C.B., Lenihan, H.S., Pandolfi, J.M., Peterson, C.H., Steneck, R.S., Tegner, M.J. Warner, R.R., 2001. Historical overfishing and the recent collapse of coastal ecosystems. Science 293, 629-638.

Jokiel, P.L., Brown, E.K., Friedlander, A., Rodgers, S., Smith, W., 2004. Hawaii coral reef assessment and monitoring program: spatial patterns and temporal dynamics in reef coral communities. Pacific Science 58, 158-174.

Joshi, S.R., 1987. Nondestructive analysis of Pb-210 and Ra-226 in sediments by direct photon analysis. Journal of Radioanalytical and Nuclear Chemistry 116, 169-182.

Jweda, J., Baskaran, M., van Hees, E., 2008. Short-lived radionuclides $\left({ }^{7} \mathrm{Be}\right.$ and $\left.{ }^{210} \mathrm{~Pb}\right)$ as tracers of particle dynamics in a river system in southeast Michigan. Limnology and Oceanography 53, 1934-1944. 
Kennedy, M.J., Chadwick, O.A., Vitousek, P.M., Derry, L.A., Hendricks, D.M., 1998 Changing sources of base cations during ecosystem development, Hawaiian Islands. Geology 26, 1015-1018.

Koch, D.M., Jacob, D.J., Graustein, W.C., 1996. Vertical transport of tropospheric aerosols as indicated by ${ }^{7} \mathrm{Be}$ and ${ }^{210} \mathrm{~Pb}$ in a chemical tracer model. Journal of Geophysical Research 101, 18,651-18,666.

Krishnaswami, S., Lal, D., Amin, B.S., Soutar, A., 1973. Geochronological studies in Santa Barbara Basin: ${ }^{55} \mathrm{Fe}$ as a unique tracer for particulate settling. Limnology and Oceanography 118, 763-770.

Liu, H., Jacob, D.J., Bey, I., Yantosca, R.M., 2001. Constraints from ${ }^{210} \mathrm{~Pb}$ and ${ }^{7} \mathrm{Be}$ on wet deposition and transport in a global three-dimensional chemical tracer model driven by assimilated meteorological fields. Journal of Geophysical Research 106, 12,109-12,128.

Long, E.R., Morgan, L.G., 1990. The Potential for Biological Effects of Sediment-sorbed Contaminants Tested in the National Status and Trends Program. National Oceanic and Atmospheric Administration. NOAA Technical Memorandum NOS OMA 52, Seattle, Washington, 143 pp.

MacDonald, G.A., Davis, G.A., Cox, D.C., 1960. Geology and Ground-water Resources of the Island of Kauai, Hawaii. Hawaii Division of Hydrography, Bulletin 13. Hawaii, Honolulu, 212 pp.

Martin, J.M., Meybeck, M., 1979. Elemental mass-balance of material carried by major world rivers. Marine Chemistry 7, 173-206.

Matisoff, G., Wilson, C.G., Whiting, P.J., 2005. The ${ }^{7} \mathrm{Be} /{ }^{210} \mathrm{~Pb}_{\mathrm{xs}}$ ratio as an indicator of suspended sediment age or fraction of new sediment in suspension. Earth Surface Processes and Landforms 30, 1191-1201.

McCulloch, M., Fallon, S., Wyndham, T., Hendy, E., Lough, J.M., Barnes, D., 2003. Coral record of increased sediment flux to the Inner Great Barrier Reef since European settlement. Nature 421, 727-730.

McLane Research Laboratories, I., 1994. Time-series sediment trap. Description available online at http://www.mclanelabs.com/mark78g21.html.

McLennan, S.M., Taylor, S.R., McCulloch, M.T., Maynard, J.B., 1990. Geochemical and $\mathrm{Nd}-\mathrm{Sr}$ isotopic compositions of deep-sea turbidites: crustal evolution and plate tectonic associations. Geochimica et Cosmochimica Acta 54, 2015-2050.

McLennan, S.M., Hemming, S., McDaniel, D.K., Hanson, G.N., 1993. Geochemical approaches to sedimentation, provenance, and tectonics. In: Johnsson, M.J., Basu, A. (Eds.), Processes Controlling the Composition of Clastic Sediment. Geological Society of America Special Paper 284, Boulder, pp. 21-40.

McNeary, D., Baskaran, M., 2003. Depositional characteristics of ${ }^{7} \mathrm{Be}$ and ${ }^{210} \mathrm{~Pb}$ in southeastern Michigan. Journal of Geophysical Research 108, 4210.

Moberly, R.M., Chamberlain, T., 1964. Hawaiian Beach Systems. University of Hawaii Institute of Geophysics Report HIG 64-2, Honolulu, Hawaii, 177 pp.

Moore, W.S., Bruland, K.W., Michel, J., 1981. Fluxes of uranium and thorium series isotopes in the Santa Barbara Basin. Earth and Planetary Science Letters 53 391-399.

Nesbit, H.W., Markovics, G., Price, R.C., 1980. Chemical processes affecting alkalis and alkaline earths during continental weathering. Geochimica et Cosmochimica Acta 44, 1659-1666.

Nozaki, Y., Thomson, J., Turekian, K.K., 1976. The distribution of ${ }^{210} \mathrm{~Pb}$ and ${ }^{210} \mathrm{Po}$ in the surface waters of the Pacific Ocean. Earth and Planetary Science Letters 21, 304-312.

Olsen, C.R., Cutshall, N.H., Larsen, I.L., 1982. Particle-pollutant associations and dynamics in coastal marine environments: a review. Marine Chemistry 11, 501-533.

Olsen, C.R., Larsen, I.L., Lowry, P.D., Cutshall, N.H., Nichols, M.M., 1986. Geochemistry and deposition of ${ }^{7} \mathrm{Be}$ in river-estuarine and coastal waters. Journal of Geophysical Research 91, 896-908.

Olsen, C.R., Thein, M., Larsen, I.L., Lowry, P.D., Mulholland, P.J., Cutshall, N.H., Byrd, J.T., Windom, H.L., 1989. Plutonium, lead-210, and carbon isotopes in the Savannah Estuary: riverbourne versus marine sources. Environmental Science \& Technology 23, 1475-1481.

Orazio, C.E., May, T.W., Gale, R.W., Meadows, J.C., Brumbaugh, W.G., Echols, K.R., Steiner, W.M., Berg, C.J., 2007. Survey of Chemical Contaminants in the Hanale River, Kauai, Hawaii, 2001. U.S. Geological Survey Scientific Investigation Report 2007-5096, 19 pp.

Pandolfi, J.M., Jackson, J.B.C., Baron, N., Bradbury, R.H., Guzman, H.M., Hughes, T.P., Kappel, C.V., Micheli, F., Ogden, J.C., Possingham, H.P., Sala, E., 2005. Are U.S coral reefs on the slippery slope to slime? Science 307, 1725-1726.

Rama, Koide, M., Goldberg, E.D., 1961. Lead-210 in natural waters. Science 134, 98-99.
Reiners, P.W., Nelson, B.K., 1998. Temporal-compositional-isotopic trends in rejuvenated-stage magmas of Kauai, Hawaii, and implications for mantle melting processes. Geochimica et Cosmochimica Acta 62, 2347-2368.

Reynolds, R.L., Rosenbaum, J.G., Hudson, M.R., Fishman, N.S., 1990. Rock magnetism, the distribution of magnetic minerals in the Earth's crust, and aeromagnetic anomalies. In: Hanna, W.F. (Ed), Geologic Applications of Modern Aeromagnetic Surveys: Proceedings of the U.S. Geological Survey Workshop on Geologic Applications of Modern Aeromagnetic Surveys, held January 6-8, 1987, in Lakewood Colorado. U.S. Geological Survey Bulletin 1924, Lakewood, CO, pp. 24-45.

Roesner, M., 2007. Geomorphic assessment of the Hanalei stream network including preliminary hydraulic gradient analysis results. In: Field, M.E., Berg, C.J. Cochran, S.A. (Eds.), Science and Management in the Hanalei Watershed: A Trans-Disciplinary Approach. USGS Open File Report 2007-1219. pp. 69-70.

Rollinson, H.R., 1993. Using Geochemical Data: Evaluation, Presentation. Interpretation. Prentice Hall, Harlow, England, 352 pp.

Rosenbaum, J.G., Reynolds, R.L., Schlinger, C.M., 1991. Effects of cooling on oxide mineralogy and magnetic properties near margins of volcanic bodies. EOS, Transactions. American Geophysical Union 72, 138.

Rosenbaum, J.G., Reynolds, R.L., Hildenbrand, T., 1994. Insight into the Structure of the East Rift Zone of Kilauea, Hawaii, from a Rock Magnetic Study of Drill Core. Proceedingsof the VIIth International Symposium on the Observation of the Continental Crust through Drilling: April 25-30, 1994, Santa Fe, New Mexico, USA.U.S. Department of Energy, pp. 142-145.

Smith, C., Hanson, K., 2007. Summary of the 2006 update to the soil survey for Hanalei watershed. In: Field, M.E., Berg, C.J., Cochran, S.A. (Eds.), Science and Management in the Hanalei Watershed: A Trans-Disciplinary Approach. USGS Open File Report 2007-1219, pp. 74-76.

Storlazzi, C.D., Presto, M.K., Logan, J.B., Field, M.E., 2006. Coastal Circulation and Sediment Dynamics in Hanalei Bay, Kauai. Part 1: Measurements of Waves, Currents, Temperature, Salinity and Turbidity: June-August 2005. U.S. Geological Survey Open File Report 2006-1085, http://pubs.usgs.gov/of/2006/ 1085. 35 pp.

Storlazzi, C.D., Presto, M.K., Logan, J.B., Field, M.E., 2008. Coastal Circulation and Sediment Dynamics in Hanalei Bay, Kaua'i, Part IV, Measurements of Waves, Currents, Temperature, Salinity, and Turbidity, June-September 2006. U.S. Geological Survey Open File Report 2008-1295, http://pubs.usgs.gov/of/2008/ 1295. 29 pp.

Storlazzi, C.D., Field, M.E., Bothner, M.H., Presto, M.K., Draut, A.E., 2009. Sedimentation processes in a coral reef embayment: Hanalei Bay, Kauai. Marine Geology 264, 140-151.

Thomson, J., Turekian, K.K., 1976. 210Po and 210Pb distributions in ocean water profiles from the eastern South Pacific. Earth and Planetary Science Letters 32, 297-303.

Tribble, G., Hill, B., 2007. Streamflow and suspended sediment load in the Hanalei River. In: Field, M.E., Berg, C.J., Cochran, S.A. (Eds.), Science and Management in the Hanalei Watershed: A Trans-Disciplinary Approach. USGS Open File Report 2007-1219, pp. 80-82.

UNEP/GPA, 2006. Protecting Coastal and Marine Environment from Impacts of Land-based Activities: A Guide for National Action. United Nations Environment Programme Global Programme of Action, The Hague, $107 \mathrm{pp}$

Wallbrink, P.J., Murray, A.S., 1996. Distribution and variability of ${ }^{7} \mathrm{Be}$ in soils under different surface cover conditions and its potential for describing soil redistribution processes. Water Resources Research 32, 467-476.

White, J., 1990. The use of sediment traps in high energy environments. Marine Geophysical Researches 12, 145-152.

Whiting, P.J., Matisoff, G., Fornes, W., Soster, F.M., 2005. Suspended sediment sources and transport distances in Yellowstone River basin. Geological Society of America Bulletin 117, 515-529.

Wilkinson, C. (Ed.), 2004. Status of Coral Reefs of the World: 2004. Volume 1. Australian Institute of Marine Science, Townsville, Queensland, $301 \mathrm{pp}$.

Windom, H.L., Schropp, S.J., Calder, F.D., Ryan, J.D., Smith, R.G., Burnery, L.C. Lewis, F.G., Rawlinson, C.H., 1989. Natural trace metal concentrations in estuarine and coastal marine sediments of the southeastern United States. Environmental Science \& Technology 23, 314-320.

Zieman, J.J., Holmes, J.L., Connor, D., Jensen, C.R., Zoller, W.H., 1995. Atmospheric aerosol trace element chemistry at Mauna Loa Observatory 1. 1979-1985. Journal of Geophysical Research 100, 25979-25994. 